\title{
LUDNOŚĆ WOJEWÓDZTWA LÓDZKIEGO: ROZWÓJ I PRZEMIANY STRUKTURALNE
}

\author{
Population of the Lódź Voivodeship: development and structural transformations
}

\author{
JERZY DZIECIUCHOWICZ*
}

\begin{abstract}
Zarys treści. Przedmiotem tego opracowania jest rozwój oraz struktura ludności województwa łódzkiego w okresie ponad stu ostatnich lat. Szczegółowej analizie podlegały przemiany ludnościowe tego regionu w czterech okresach: 1) do 1918 roku, 2) 1918-1945, 3) 1946-1989, 4) 1990-2018. Uwzględniono również prognozę demograficzną dla województwa do $2050 \mathrm{r}$. Strukturę ludności rozpatrywano, biorąc pod uwagę jej podział według cech demograficznych, społeczno-ekonomicznych, społeczno-kulturowych i przestrzennych. Zasadniczym celem pracy było ustalenie ogólnych tendencji w rozwoju i restrukturalizacji ludności województwa łódzkiego oraz jej typologii przestrzennej.

Słowa kluczowe: region łódzki, rozwój demograficzny, struktura demograficzna, struktura i typologia przestrzenna ludności
\end{abstract}

\begin{abstract}
The subject of this study was the development and structural transformation of the population of the Lódź Voivodeship over the last more than one hundred years. Population transformations were analysed for four periods: 1) pre-1918; 2) 1918-1945; 3) 1946-1989; and 4) 1990-2018. A demographic forecast of the Łódź Voivodeship was made up to 2050. The structure of the population of the investigated region was considered, taking into consideration the population according to demographic, socio-economic and socio-cultural divisions and spatial features. The basic aim of the author was to establish general tendencies in the development and restructuring of the population of the Lódź region and its spatial typology.

Key words: Łódź province, Łódź region, demographic development, demographic structure, structure and spatial typology of population
\end{abstract}

\section{Uwagi wstępne}

Obecna sytuacja ludnościowa województwa łódzkiego wywiera wpływ na kształtowanie jego regionalnego systemu przestrzennego, obejmującego infrastrukturę społeczną, mieszkalnictwo, rynek pracy, przemysł oraz transport i komunikację (Klaassen i in. 1982). W rozwoju ludności tego regionu następowały zmiany związane z pierwszym i drugim przejściem demograficznym. Pierwsze przejście demograficzne prowadziło od tradycyjnej reprodukcji ludności do nowoczesnej, natomiast drugie wyrażało się spadkiem płodności, warunkującym zawężoną reprodukcję ludności, z czym związane było dynamiczne starzenie demograficzne, wywierające istotny wpływ na życie społeczne i gospodarcze rozpatrywanego regionu. Społeczności miejscowe pozostają pod wpływem dwóch przeciwstawnych sił: różnicujących i unifikujących. $\mathrm{Na}$ rozwój społeczny i demograficzny województwa silny wpływ wywarła transformacja systemowa zapoczątkowana w 1989 r. (Werwicki 1998). Odrębny czynnik zewnętrzny stanowią procesy globalizacji oddziałujące na jego gospodarkę i więzi terytorialne (Bauman 2000).

Region łódzki wyróżnia się indywidualnymi cechami rozwoju demograficznego i uzależnionej od niego struktury przestrzennej ludności. Wzrost potencjału ludnościowego tego regionu osiągnął wyjątkowo wysoką dynamikę w dobie intensywnego uprzemysłowienia w XIX w. Współcześnie główną składową przemian demograficznych w województwie łódzkim, podobnie jak w wielu innych tzw. kurczących się regionach (shrinking regions) Europy, stała się depopulacja, powiązana $\mathrm{z}$ procesem starzenia demograficznego. Przeciwdziałanie temu wyludnianiu wymaga radykalnej poprawy jakości życia mieszkańców i sytuacji na rynku pracy, a także wzrostu zasobów i kwalifikacji siły roboczej.

Przedmiotem tego opracowania jest rozwój oraz przemiany strukturalne ludności regionu łódzkiego w okresie ponad stu ostatnich lat.

* Uniwersytet Łódzki, Wydział Nauk Geograficznych, Instytut Zagospodarowania Środowiska i Polityki Przestrzennej, ul. Kopcińskiego 31, 90-142 Łódź; e-mail: jerzy.dzieciuchowicz@geo.uni.lodz.pl 
Szczegółowej analizie podlegały zmiany ludnościowe w województwie łódzkim zachodzące w czterech okresach: 1) do 1918 roku, 2) 19181945, 3) 1946-1989, 4) 1990-2018. Uwzględniona została również prognoza demograficzna dla województwa do 2050 r. Strukturę ludności badanego regionu rozpatrywano, biorąc pod uwagę jej podział według cech demograficznych, społecznoekonomicznych, społeczno-kulturowych i przestrzennych. Zakres przestrzenny pracy obejmuje województwo łódzkie $\mathrm{z}$ reguły $\mathrm{w}$ jego każdorazowych granicach administracyjnych. Tylko niektóre dane dotyczące rozwoju ludności województwa w latach 1950-1988, zostały przeliczone według podziału administracyjnego na dzień 1.01.1999 r. Zasadniczym celem pracy było ustalenie ogólnych tendencji w rozwoju i przekształceniach strukturalnych ludności regionu łódzkiego oraz jej typologia przestrzenna.

Praca opiera się głównie na materiałach pochodzących z bieżącej ewidencji statystycznej ludności oraz spisów powszechnych i badań okresowych. Odwoływano się również do wyników badań terenowych. Wykorzystana literatura przedmiotu wchodzi w głównej mierze w zakres geografii ludności i demografii regionu łódzkiego. Szczególną uwagę zwrócono na opracowania dotyczące rozwoju ludności i przemian jej struktury w regionie łódzkim, opublikowane przez Straszewicza (1967), Rosina (1970), Dzieciuchowicza (1998a, b, 2001, 2002, 2014), Olejnika (2009), Rzepkowskiego (2009) i Szukalskiego (2015). Dla części tej pracy podstawą odniesienia była problematyka redystrybucji przestrzennej ludności regionu łódzkiego, rozpatrywana m.in. w pracach Dylika (1948), Straszewicza (1967), Dzieciuchowicza (1989, 1995, 1998a, b) oraz Michalskiego (1995).

\section{Ludność województwa lódzkiego do 1918 roku}

Na terenie regionu łódzkiego ludzie osiedlali się już w środkowym paleolicie (Koter i in. 1999). Najstarsze ślady pobytu człowieka neandertalskiego na tym obszarze, datowane na 130-8,9 tys. lat p.n.e., zostały odkryte w rejonie Góry Św. Małgorzaty (położonej w pobliżu Łęczycy). W starożytności rozwój ludnościowy regionu był związany w głównej mierze z rozprzestrzenianiem się stałego osadnictwa w jego północnej części na obszarze Pradoliny Warszawsko-Berlińskiej, gdzie żyzne gleby oraz łąki i pastwiska sprzyjały rozwojowi gospodarki rolnej (Dylik 1948; Pączka 1993) (rys. 1). W epoce żelaza rolnictwo wkroczyło na tereny położone w środkowym biegu Neru i Bzu- ry. Warto przy tym zauważyć, iż w okresie kultury łużyckiej (a także w późniejszych wiekach) większa część regionu, pokryta lasami, nie była atrakcyjna dla osadnictwa powiązanego z rolnictwem. Dopiero od połowy I w. n.e. do końca IV wieku n.e. (kultura wenedzka) wpływy rzymskie przyczyniły się do rozwoju osadnictwa w dolinach największych rzek regionu, jak też ich dopływów, przenikając stopniowo na tereny wododziałowe Wzniesień Łódzkich.

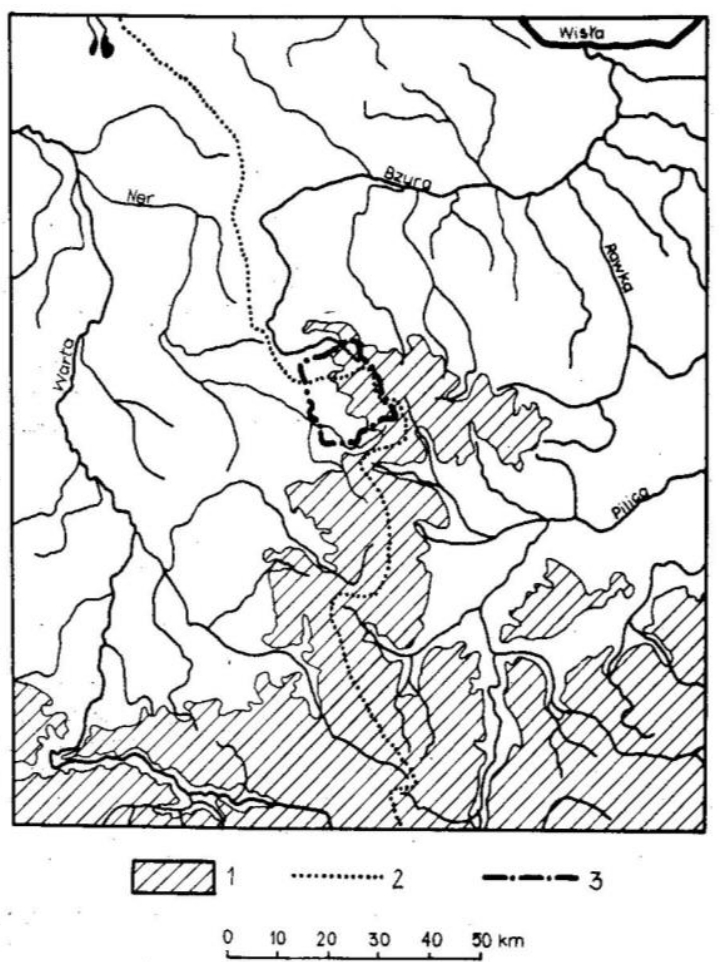

Rys. 1. Położenie geograficzne regionu Łodzi (Dylik 1948)

1 - tereny powyżej $200 \mathrm{~m}$ n.p.m., 2 - dział wodny dorzecza Wisły i Odry, 3 - granice współczesnej Łodzi

Geographical location of Łódź region (Dylik 1948)

$$
\begin{gathered}
1 \text { - areas above } 200 \mathrm{~m} \text { a.s.l., } 2 \text { - watershed } \\
\text { of the riverbasin of the Vistula and the Oder, } \\
3 \text { - border of contemporary Łódź }
\end{gathered}
$$

Na początku średniowiecza rozwój ludnościowy w regionie łódzkim był powolny. Wpłynęły na to częste klęski żywiołowe i epidemie, a także rozpad dawnych wspólnot rodowych i powolne tworzenie nowych hierarchicznych wspólnot terytorialnych. Wyraźny wzrost demograficzny cechował jedynie rejony nowo zagospodarowane, przechodzące $\mathrm{w}$ rolnictwie od systemów odłogowych do uprawowych, a także tam, gdzie wprowadzano do użytku nowe rodzaje roślin uprawnych. Ludność regionu była wówczas skupiona przede wszystkim $\mathrm{w}$ rejonie Łęczycy i w dolinie Warty. Dość wysoki jej odsetek stano- 
wili przy tym mieszkańcy miast. W XIV w. gęstość zaludnienia tego obszaru dochodziła do 20 osób $/ \mathrm{km}^{2}$, podczas gdy na Wzniesieniach Łódzkich, w Kotlinie Szczercowskiej i na Wysoczyźnie Bełchatowskiej nie przekraczała nawet 2 osób $/ \mathrm{km}^{2}$. W końcu XVI w. średnia gęstość zaludnienia regionu przewyższała 22 osoby $/ \mathrm{km}^{2}$, obniżając się podczas dwu następnych stuleci w wyniku wojen ze Szwedami. Dane pierwszego spisu ludności Polski z 1790 r. dla województw sieradzkiego i łęczyckiego (16 tys. $\mathrm{km}^{2}$ ), pomiędzy które było podzielone obecne województwo łódzkie, wskazują, że zamieszkiwało tam wówczas 388 tys. osób, przy przeciętnej gęstości 24 osób na $1 \mathrm{~km}^{2}$ (Janczak 2001).

Ogromne przyśpieszenie tempa wzrostu demograficznego w regionie łódzkim zostało zapoczątkowane w XIX w. (Janczak 2001), dzięki rozwojowi przemysłu i urbanizacji. Od roku 1819 do 1897 liczba ludności regionu wzrosła z 636,7 tys. do 1989,2 tys., tj. ponad trzykrotnie (tab. 1). Równocześnie $\mathrm{w}$ takim samym stopniu zwiększyła się gęstość zaludnienia (z 28,6 do 89,4 osób/ $/ \mathrm{km}^{2}$ ). Szczególnie intensywny wzrost demograficzny cechował miasta. O ile w latach dwudziestych XIX w. 63 miasta regionu liczyły łącznie około
100 tys. mieszkańców, to w końcu tego stulecia ich zaludnienie wzrosło aż do 650 tys. Należy przy tym zwrócić szczególną uwagę na żywiołowy wzrost demograficzny Łodzi, zdeterminowany niezwykle dynamicznym rozwojem przemysłu włókienniczego (Dzieciuchowicz 2014). W latach 1820-1914 liczba jej mieszkańców zwiększyła się ponad 623 razy (z 767 osób do 477,9 tys.). Tę tendencję rozwojową doskonale aproksymuje dodatnia funkcja wykładnicza.

Aż do końca XVIII w. przyrost naturalny $\mathrm{W}$ regionie łódzkim był niewielki. Wynikało to z utrzymywania się zarówno wysokiej rodności (>40\%), jak i umieralności (około 40\%), podlegającej częstym wahaniom. W teorii transformacji demograficznej sytuacja taka odpowiada naturalnemu systemowi demograficznemu. W XIX w. region wszedł $\mathrm{w}$ następną fazę, określaną $\mathrm{w}$ tej teorii mianem ,rewolucji demograficznej”. Cechowało ją nadal wysokie natężenie urodzeń (40$45 \%$ ), przy równoczesnej stabilizacji poziomu umieralności w pierwszej połowie XIX w. i jego spadku $(<30 \%)$ w drugiej połowie tego stulecia. Kolejna faza przejścia demograficznego została zapoczątkowana $\mathrm{w}$ omawianym regionie przed I wojną światową, gdy nastąpił spadek rodności.

Tabela 1

Ludność regionu łódzkiego w XIX w. (za: Janczak 2001)

The population of Łódź region in the 19th century (after: Janczak 2001)

\begin{tabular}{|c|c|c|c|}
\hline $\begin{array}{l}\text { Rok } \\
\text { Year }\end{array}$ & $\begin{array}{c}\text { Powierzchnia w tys. } \mathrm{km}^{2} \\
\text { Area in thousands of } \mathrm{km}^{2}\end{array}$ & $\begin{array}{c}\text { Ludność w tys. } \\
\text { Population in thousands }\end{array}$ & $\begin{array}{c}\text { Osób na } \mathrm{km}^{2} \\
\text { Persons } \text { on }^{2} \mathrm{~km}^{2}\end{array}$ \\
\hline 1819 & 22,6 & 636,7 & 28,6 \\
\hline 1864 & 22,6 & 1096,5 & 48,4 \\
\hline 1870 & 18,9 & 972,8 & 51,5 \\
\hline 1897 & 18,9 & 1989,2 & 89,4 \\
\hline
\end{tabular}

Na rozwój ludności regionu łódzkiego w XIX w. wpływał też wysoki przyrost migracyjny. Był on skutkiem podjętej przez władze Królestwa Polskiego planowej akcji uprzemysłowienia kraju poprzez wspieranie osadnictwa niemieckiego, które początkowo miało w głównej mierze charakter rolniczy. Pod koniec lat dwudziestych XIX w. jego skala była największa w guberni piotrkowskiej, gdzie osiedliło się około 150 tys. Niemców $(10,6 \%$ ogółu ludności). Większość z nich była skupiona w powiatach łódzkim (wraz z Łodzią), brzezińskim i łaskim. W Łodzi udział Niemców dochodził wtedy do $25 \%$, malejąc w późniejszych latach. $\mathrm{Na}$ początku lat 30 . XIX w. liczba ludności niemieckiej w ówczesnym województwie łódzkim zmniejszyła się do 130 tys. W XIX w. województwo to stało się równocześnie ogromnym skupiskiem ludności żydowskiej, napływającej głów- nie do miast. Tym sposobem ukształtowała się wielonarodowościowa struktura ludności województwa. Po uwłaszczeniu chłopów nasilił się ich napływ do uprzemysławianych miast regionu łódzkiego, w szczególności ośrodków Łódzkiego Okręgu Przemysłowego.

\section{Ludność województwa lódzkiego w latach 1918-1945}

\section{Rozwój ludności}

Województwo łódzkie, stanowiące jednostkę podziału administracyjnego II stopnia Rzeczypospolitej Polskiej, zostało utworzone w 1919 r. (2 VIII). Powołanie województwa było ważnym impulsem dla jego rozwoju społeczno-ekonomicz- 
nego i demograficznego. W skład województwa, zajmującego powierzchnię około 19 tys. $\mathrm{km}^{2}$, początkowo weszło, czternaście powiatów ${ }^{1}$, obejmujących tereny dawnych ziem: łęczyckiej i rawskiej, od 1867 r. należących do guberni piotrkowskiej i kaliskiej. Szacunkowe dane wskazują, że łącznie z Łodzią skupiały one 2436,7 tys. mieszkańców. Z dokładniejszych danych spisu ludności z $1921 \mathrm{r}$. wynika, że na tym obszarze zamieszkiwało 2252,8 tys. osób (tab. 2). Województwo łódzkie należało wówczas do największych skupisk ludnościowych w kraju. Większe pod tym względem były tylko 3 województwa: warszawskie, lwowskie i kieleckie. Średnia gęstość zaludnienia województwa łódzkiego osiągnęła wtedy 118 osób $/ \mathrm{km}^{2}$.

Tabela 2

Ludność województwa łódzkiego w latach 1921-1939

(za: Narodowy Spis Powszechny 1921, 1931; Badziak i in. 2009)

Population of Łódź Voivodeship, 1921-1939

(after: Narodowy Spis Powszechny 1921, 1931; Badziak et al. 2009)

\begin{tabular}{|l|c|c|c|}
\hline $\begin{array}{l}\text { Wyszczególnienie } \\
\text { Specification }\end{array}$ & 1921 & 1931 & 1939 \\
\hline $\begin{array}{l}\text { Powierzchnia w tys. km² } \\
\text { Area in } \mathrm{km}^{2} \text { thousands }\end{array}$ & 19,03 & 19,09 & 20,69 \\
\hline $\begin{array}{l}\text { Ludność w tys. } \\
\text { Population in thousands }\end{array}$ & 2252,8 & 2632,0 & 2690,0 \\
\hline $\begin{array}{l}\text { Osób na km } \mathrm{km}^{2} \\
\text { Persons } \text { on } \mathrm{km}^{2}\end{array}$ & 118 & 138 & 130 \\
\hline
\end{tabular}

Kolejny spis ludności z 1931 r. wykazał wzrost liczby mieszkańców województwa łódzkiego do 2632 tys., tj. o 379, 2 tys. (16,8\%). Chociaż w liczbach bezwzględnych wzrost ten można uznać za dość wysoki, to jednak tempo rozwoju demograficznego omawianego regionu było wówczas znacznie mniejsze w porównaniu z przełomem XIX i XX w. Można przy tym zauważyć, że ludność Łodzi rozwijała się wtedy dużo szybciej niż populacja całego województwa, wzrosła bowiem wtedy z 452,0 tys. do 604,6 tys., tj. o 152,6 tys. czyli o 33,8\%). Rok 1938 r. (1 IV) przyniósł zmianę granic województwa łódzkiego, wskutek której do woj. poznańskiego przeszły cztery powiaty ${ }^{2}$. Województwo łódzkie utraciło wtedy na rzecz woj. poznańskiego $6317 \mathrm{~km}^{2}$ i 625 tys. mieszkańców. Straty te zostały zrekompensowane w wyniku kolejnej zmiany podziału administracyjnego Polski w 1939 r. (1 IV). W jej wyniku granice województwa ${ }^{3}$ uległy rozszerzeniu na północy i wschodzie, a jego powierzchnia zwiększyła się do 20,7 tys. $\mathrm{km}^{2}$. Równocześnie liczba mieszkańców wzrosła do 2690 tys., natomiast gęstość zaludnienia obniżyła się do 130 osób/km². Spadek tej gęstości był związany z przyłączeniem wielu powiatów o dość dużej powierzchni i małych zasobach ludnościowych. W ówczes- nych warunkach, ze względu na wysoki udział ludności miejskiej (41\%), województwo łódzkie można uznać za dość silnie zurbanizowane.

Na początku okresu międzywojennego wysoki przyrost rzeczywisty ludności w województwie łódzkim wynikał z działania tendencji kompensacyjnej po I wojnie światowej, związanej z wysokim natężeniem zawieranych małżeństw i urodzeń, a także intensywnych migracji. Po kilku latach nastąpił jednak spadek współczynnika urodzeń, szczególnie duży w samej Łodzi (do około 18\%o). Pogorszenie sytuacji gospodarczej regionu w latach 1931-1935 spowodowało, że współczynnik przyrostu naturalnego obniżył się tam do 10,4\%o (tab. 3). Poważnym problem była też emigracja zagraniczna mieszkańców województwa. W latach 1927-1937 z tego regionu wyjechało za granicę na stałe ogółem 84,8 tys. osób, przy czym najwięcej do Francji (63 tys.). Dużo mniejsze znaczenie miała emigracja do Palestyny (7,7 tys.), Argentyny (2,4 tys.), Kanady (1,8 tys.) i Stanów Zjednoczonych (1,6 tys.). Sezonowo najwięcej osób wyjechało wówczas do Niemiec (186,7 tys.). Równocześnie stan ludności województwa w latach 1918-1924 powiększył się dzięki repatriacji.

\footnotetext{
${ }^{1}$ Chodzi tu o następujące powiaty ziemskie: brzeziński, kaliski, kolski, koniński, łaski, łódzki, łęczycki, piotrkowski, radomszczański, sieradzki, słupecki, turecki, wieluński oraz powiat łódzki grodzki.

${ }^{2}$ Były to powiaty: kaliski, kolski, koniński i turecki.

${ }^{3}$ Do województwa zostały włączone cztery powiaty z woj. warszawskiego (kutnowski, łowicki, skierniewicki i rawski) oraz dwa powiaty z woj. kieleckiego (opoczyński i konecki - bez gmin wiejskich Bliżyn i Szydłowiec). Łącznie województwo składało się z 15 powiatów.
} 
Ruch naturalny ludności województwa łódzkiego w latach 1931-1935 (przeciętne roczne) (za: Mały Rocznik Statystyczny 1938)

Natural population movement of the Łódź Voivodeship, 1931-1935 (annual averages) (after: Mały Rocznik Statystyczny 1938)

\begin{tabular}{|l|c|c|}
\hline \multicolumn{1}{|c|}{$\begin{array}{c}\text { Wyszczególnienie } \\
\text { Specification }\end{array}$} & $\begin{array}{c}\text { W tysiącach } \\
\text { In thousands }\end{array}$ & $\begin{array}{c}\text { W \%o } \\
\text { In \%o }\end{array}$ \\
\hline $\begin{array}{l}\text { Małżeństwa } \\
\text { Marriages }\end{array}$ & 24 & 8,7 \\
\hline $\begin{array}{l}\text { Urodzenia } \\
\text { Births }\end{array}$ & 67 & 24,7 \\
\hline $\begin{array}{l}\text { Zgony } \\
\text { Deaths }\end{array}$ & 39 & 14,3 \\
\hline $\begin{array}{l}\text { Przyrost naturalny } \\
\text { Natural increase }\end{array}$ & 28 & 10,4 \\
\hline
\end{tabular}

\section{Struktura ludności}

Struktura społeczno-ekonomiczna ludności województwa łódzkiego w okresie międzywojennym była silnie zróżnicowana (Rzepkowski 2009). W 1921 r. w strukturze tej czołową pozycję zajmowały osoby samodzielne $(39,9 \%)$. Była to grupa złożona z właścicieli różnej wielkości firm przemysłowych i usługowych oraz gospodarstw rolnych. Istotne miejsce zajmowali w niej przedstawiciele klasy średniej o wysokich dochodach. O robotniczym charakterze województwa świadczy fakt, iż w omawianej strukturze na drugim miejscu pod względem liczebności znajdowali się robotnicy i chałupnicy $(34,1 \%)$. Dość liczną grupę tworzyli też pomagający członkowie rodzin. Jednocześnie w strukturze tej zwraca uwagę niewielki udział pracowników umysłowych $(3,8 \%)$. Na początku lat 30., podczas kryzysu gospodarczego, w strukturze społecznej ludności województwa wydatnie wzrósł udział pracowników samodzielnych (do 53,2\%), a także robotników i chałupników (40,4\%).

Należy również zaznaczyć, iż w podziale źródeł utrzymania ludności całego regionu dominowało wówczas rolnictwo $(49,0 \%)$, chociaż równocześnie dość duże znaczenie miał tu przemysł $(31,4 \%)$ (tab. 4). Wskutek industrializacji w latach 1921-1931 udział przemysłu w tej strukturze wzrósł (o 6,7\%), natomiast zmalał udział rolnictwa (o 4,7\%). Źródła utrzymania ludności były silnie zróżnicowane w zależności od wyznań. W przypadku przedstawicieli wyznania katolickiego największy udział w tych źródłach miało rolnictwo (58\%), wśród osób wyznania ewangelickiego przemysł (42\%), a mojżeszowego - handel (32\%). Trzeba również podkreślić, iż w omawianym okresie ludność województwa była słabo wykształcona. Na początku lat 20. świadczył o tym z jednej strony wysoki odsetek analfabetów (42,2\%) i osób z wykształceniem początkowym, a z drugiej niski udział osób, które zdobyły wykształcenie średnie (2,9\%) i wyższe $(0,2 \%)$. Nie umiało wtedy czytać ani pisać aż 30,3\% osób w wieku 10 lat i więcej. Późniejszy rozwój szkolnictwa podstawowego w województwie spowodował, że w 1931 r. poziom analfabetyzmu obniżył się istotnie (do 21,4\%).

W okresie międzywojennym społeczeństwo województwa łódzkiego było też podzielone pod względem społeczno-kulturowym. Dowodzi tego zarówno jego struktura narodowościowa, językowa, jak też wyznaniowa (tab. 5). Zdecydowaną większość w całym województwie stanowiła ludność deklarująca narodowość polską, ojczysty język polski i wyznanie katolickie. Według danych spisu z 1921 r., Polacy stanowili aż 83,1\% ogółu ludności województwa, podczas gdy udział Żydów dochodził do 12,0\%, a Niemców do 4,5\%. Inne, nieliczne narodowości były reprezentowane w szczególności przez Rosjan, Rusinów (Ukraińców), Białorusinów, Czechów i Litwinów. Podział narodowościowy mieszkańców województwa był w znacznej mierze powiązany z ich strukturą językową i wyznaniową. Dane spisu z 1931 r. wskazują, że w przypadku języka ojczystego język polski był deklarowany przez 80,1\% ogółu ludności, natomiast żydowski (z hebrajskim) przez 13,6\%, a niemiecki przez 5,9\%. Dysproporcje w strukturze językowej były bardzo wyraźnie widoczne pomiędzy miastami i wsią. O ile udział ludności używającej języka polskiego w miastach dochodził do $62,6 \%$, to na wsi wzrastał aż do $92,7 \%$. Językiem żydowskim w miastach posługiwało się $29,8 \%$ osób, a na wsi tylko $2 \%$. W przypadku języka niemieckiego różnice między ludnością miejską $(7,3 \%)$ i wiejską $(4,9 \%)$ były dużo mniejsze. Jednocześnie znaczne zróżnicowanie cechowało dosyć trwałą strukturę wyznaniową ludności województwa. W 1931 r. udział katolików osiągał tutaj 77,5\% ogółu ludności, osób wyznania mojżeszowego $14,3 \%$, a protestanckiego jedynie $7,1 \%$. Inne wyznania odgrywały marginalną rolę (tab. 5). 
Ludność województwa łódzkiego według źródeł utrzymania w 1921 i 1931 r.

(za: Narodowy Spis Powszechny 1921, 1931)

Income sources of the Łódź Voivodeship population, 1921 and 1931

(after: Narodowy Spis Powszechny 1921, 1931)

\begin{tabular}{|l|c|c|c|c|}
\hline \multirow{2}{*}{$\begin{array}{l}\text { Źródło utrzyma- } \\
\text { nia Employment } \\
\text { sectors }\end{array}$} & $\begin{array}{l}|c| \\
\text { Liczba ludności w tys. } \\
\text { Number of population }\end{array}$ & $\%$ & $\begin{array}{c}\text { Liczba ludności w tys. } \\
\text { Number of population }\end{array}$ & $\%$ \\
\hline $\begin{array}{l}\text { Razem } \\
\text { Total }\end{array}$ & $\mathbf{2 2 5 2 , 8}$ & $\mathbf{1 0 0 , 0}$ & $\mathbf{2 6 3 2 , 0}$ & $\mathbf{1 0 0 , 0}$ \\
\hline $\begin{array}{l}\text { Rolnictwo } \\
\text { Agriculture }\end{array}$ & 1210,9 & 53,7 & 1292,3 & 49,0 \\
\hline $\begin{array}{l}\text { Przemysł } \\
\text { Industry }\end{array}$ & 556,6 & 24,7 & 827,7 & 31,4 \\
\hline $\begin{array}{l}\text { Handel } \\
\text { Commerce }\end{array}$ & 187,4 & 8,3 & 214,7 & 8,1 \\
\hline $\begin{array}{l}\text { Komunikacja } \\
\text { Communication }\end{array}$ & 61,8 & 2,7 & 79,1 & 8,0 \\
\hline $\begin{array}{l}\text { Pozostałe } \\
\text { Other sectors }\end{array}$ & 236,1 & 10,6 & 218,2 & 8,5 \\
\hline
\end{tabular}

Tabela 5

Struktura wyznaniowa ludności województwa łódzkiego w latach 1921 i 1931

(za: Narodowy Spis Powszechny 1921, 1931)

The religious structure of the Łódź Voivodeship population, 1921and 1931 (after: Narodowy Spis Powszechny 1921, 1931)

\begin{tabular}{|l|c|c|c|c|}
\hline \multirow{2}{*}{$\begin{array}{l}\text { Wyznanie } \\
\text { Denomination }\end{array}$} & $\begin{array}{c}|c| \\
\text { Liczba osób } \\
\text { Number of persons }\end{array}$ & $\%$ & $\begin{array}{c}\text { Liczba osób } \\
\text { Number of persons }\end{array}$ & $\%$ \\
\cline { 2 - 5 } $\begin{array}{l}\text { Razem } \\
\text { Total }\end{array}$ & $\mathbf{2 2 5 2} \mathbf{7 6 9}$ & $\mathbf{1 0 0 , 0}$ & $\mathbf{2 ~ 6 3 2 ~ 0 1 0}$ & $\mathbf{1 0 0 , 0}$ \\
\hline $\begin{array}{l}\text { Katolickie } \\
\text { Catholic }\end{array}$ & 1734117 & 76,9 & 2041570 & 77,5 \\
\hline $\begin{array}{l}\text { Mojżeszowe } \\
\text { Jewish }\end{array}$ & 326973 & 14,5 & 378495 & 14,3 \\
\hline $\begin{array}{l}\text { Protestanckie } \\
\text { Protestant }\end{array}$ & 173546 & 7,7 & 187904 & 7,1 \\
\hline $\begin{array}{l}\text { Inne } \\
\text { Other }\end{array}$ & 18133 & 0,8 & 24031 & 0,8 \\
\hline
\end{tabular}

Zasoby ludnościowe na obszarze województwa łódzkiego były podzielone nierównomiernie pomiędzy poszczególne powiaty. W $1931 \mathrm{r}$. do powiatów o największej liczbie ludności należał powiat grodzki łódzki $(38,6 \%)$ oraz powiaty ziemskie: piotrkowski i wieluński (rys. 2). Gęstość zaludnienia przewyższającą średnią dla całego regionu $\left(130 \mathrm{osób} / \mathrm{km}^{2}\right)$ notowano w powiatach położonych w granicach Łódzkiego Okręgu Przemysłowego, tj. oprócz samej Łodzi, w powiatach ziemskich: łódzkim i brzezińskim (rys. 2, 3).
Mieszkało tam wtedy 917 tys. osób, stanowiących 34\% ogółu ludności województwa łódzkiego ${ }^{4}$.

\section{Mieszkańcy województwa lódzkiego podczas II wojny światowej}

Wskutek II wojny światowej nastąpił olbrzymi ubytek ludności województwa łódzkiego. Jego wielkość dochodziła aż do 862 tys. osób. Tylko w części był on spowodowany działaniami wo-

\footnotetext{
${ }^{4}$ Uwzględniając cały powiat konecki.
} 


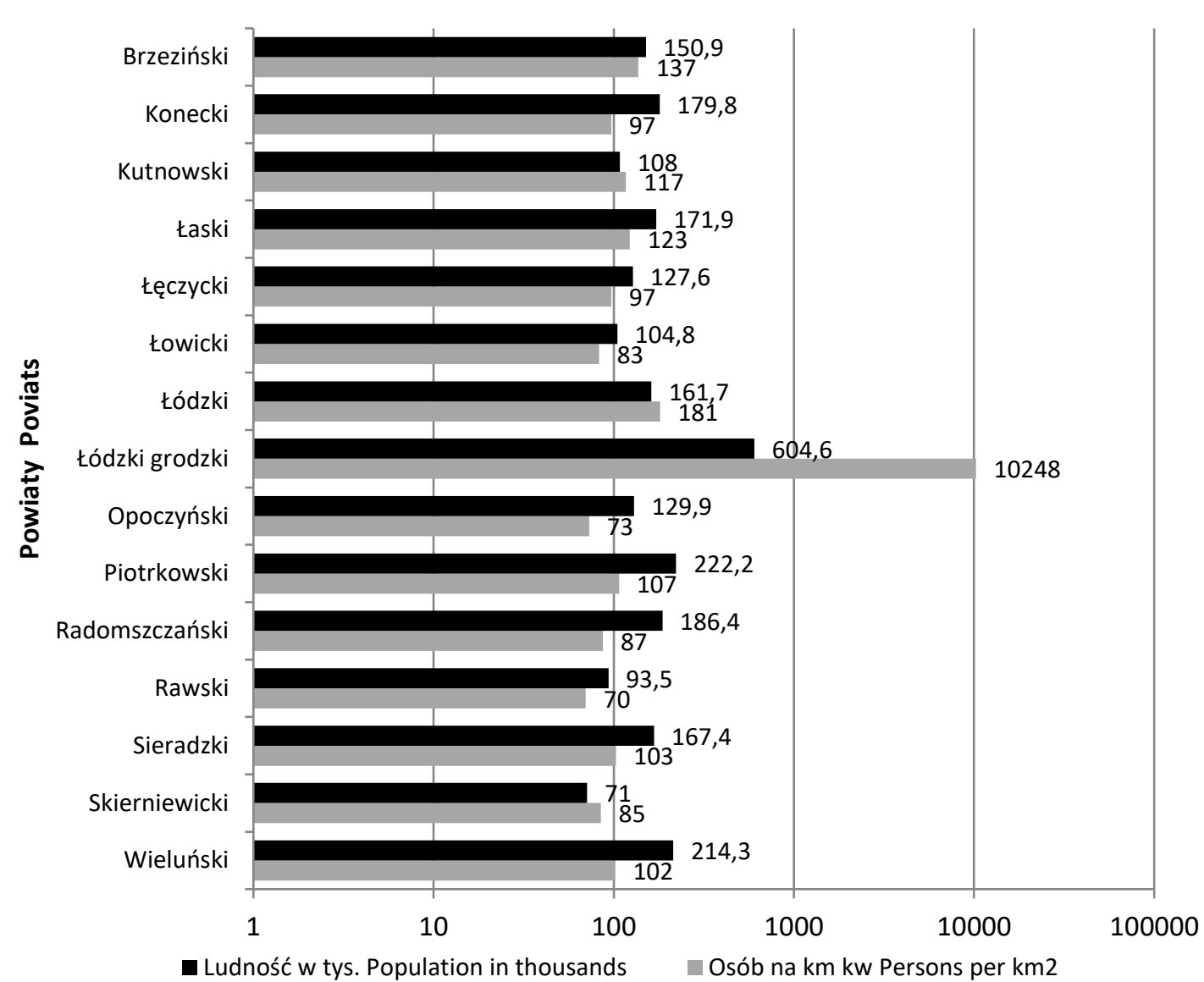

Rys. 2. Liczba ludności i gęstość zaludnienia według powiatów w województwie łódzkim w $1931 \mathrm{r}$. (wartości na osi poziomej zlogarytmowane) (za: Mały Rocznik Statystyczny 1938)

Population number and density by poviat in the Łódź Voivodeship, 1931 (values on the horizontal pivot in logarithms (after: Mały Rocznik Statystyczny 1938)

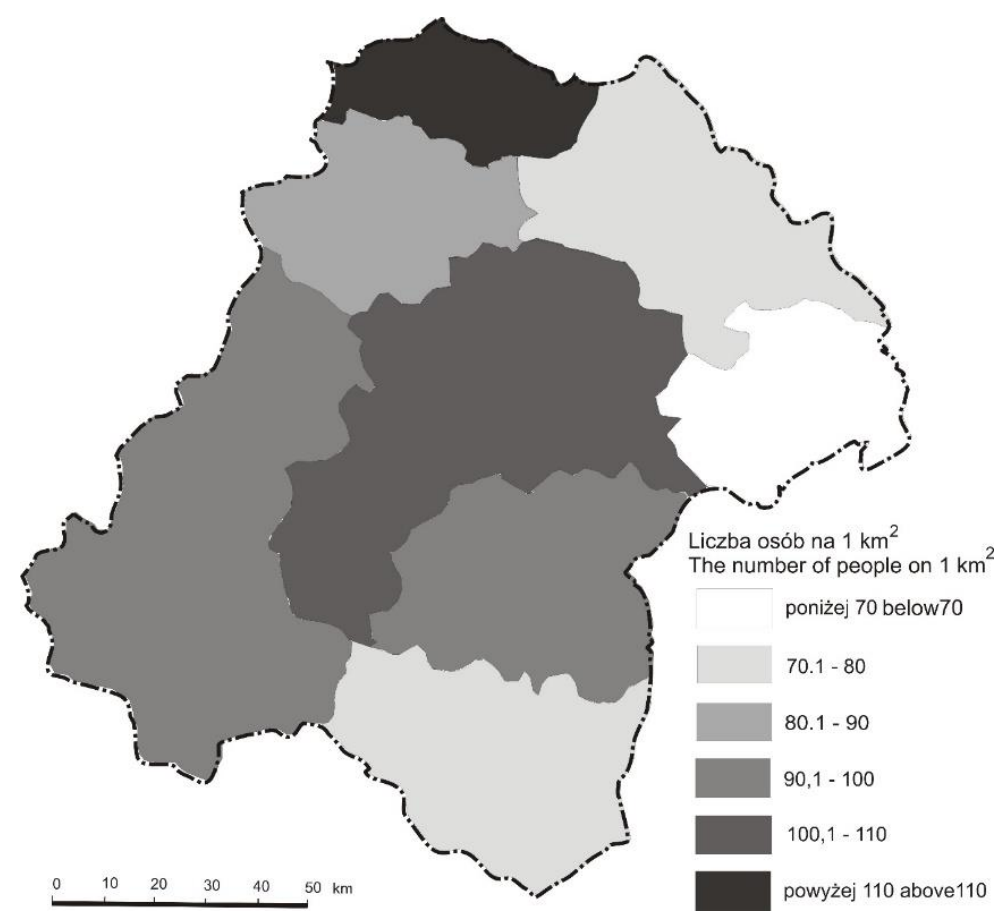

Rys. 3. Gęstość zaludnienia województwa łódzkiego w 1931 r. (granice z 1964 r.) (za: Straszewicz 1967)

Population density of the Łódź Voivodeship, 1931 (border from 1964) (after: Straszewicz 1967) 
jennymi. Z terenów województwa włączonych w skład Rzeszy (Kraj Warty, Wartegau) Niemcy wysiedlili większość ludności polskiej, a Żydów wymordowali. Do spadku liczby ludności regionu (oprócz strat biologicznych), przyczyniły się wzmożone migracje, a zwłaszcza ucieczka znacznej części ludności, masowe wywózki do obozów koncentracyjnych i na roboty przymusowe do Niemiec, a także ujemny przyrost naturalny.

Regres demograficzny związany z wojną niemal w równym stopniu dotknął Łódź i resztę województwa. Według danych szacunkowych (Ginsbert 1962) od wybuchu wojny w dniu 1 września 1939 r. do wyzwolenia miasta 19 stycznia 1945 r. liczba ludności Łodzi zmniejszyła się z 680 tys. do 250 tys., czyli o 430 tys. Oznacza to, że miasto utraciło aż $2 / 3$ swoich mieszkańców. Większość z nich (279 tys.) została wymordowana przez okupanta, w tym około 170 tys. Żydów (Puś 1987). W latach 1939-1946 w województwie łódzkim (w granicach z 1973 r. bez Łodzi) liczba ludności zmniejszyła się o 432 tys. Wskutek wojny znacznie zdeformowana została struktura ludności, zwłaszcza według płci i wieku, a struktury narodowościowa i wyznaniowa stały się prawie jednorodne.

\section{Ludność województwa lódzkiego w okresie 1946-1988}

\section{Rozwój ludności województwa (w obecnych granicach)}

Analizę danych demograficznych dotyczących województwa łódzkiego w latach powojennych utrudniają wielokrotne zmiany podziału administracyjnego Polski. Zgodnie z dekretem PKWN z 11 września 1945 r., przywrócono podział sprzed 1939 r., przy czym Łódź stała się miastem wydzielonym na prawach województwa. $Z$ niedużymi zmianami (wyłączenie z granic województwa powiatu opoczyńskiego i koneckiego w 1950 r.) podział ten przetrwał aż do 22 kwietnia $1975 \mathrm{r}$. Wprowadzone wtedy wbrew tradycji historycznej i utrwalonym więziom regionalnym nowe, znacznie zawężone, granice województwa obejmowały głównie obszar $\left(1523 \mathrm{~km}^{2}\right)$ Łódzkiej Aglomeracji Miejskiej. Do wprowadzenia, obecnie obowiązującego podziału administracyjnego, zbliżonego do stanu sprzed 1975 r., doszło dopiero 1 stycznia 1999 roku.
Po zakończeniu II wojny światowej oraz ustabilizowaniu sytuacji politycznej i społeczno-ekonomicznej, w okresie PRL, następował systematyczny wzrost potencjału demograficznego województwa łódzkiego. Biorąc pod uwagę liczbę ludności tego województwa, przeliczoną według podziału administracyjnego z dnia 1 I 1999 r. (Gawryszewski 2005), można zauważyć, że od 1950 do 1988 r. zwiększyła się ona z 2140,8 tys. do 2703,7 tys., tj. o 562,9 tys. (rys. 4 ; tab. 6), czyli o $26,3 \%$. Równocześnie znacząco wzrosła też gęstość ludności regionu (z 116 do 148 osób/ km²). Jednakże po kilku latach powojennych i wygaśnięciu fazy kompensacyjnej tempo rozwoju demograficznego województwa stopniowo malało. Trzeba przy tym zauważyć, że w tym samym czasie wzrostowi liczby ludności miejskiej towarzyszył ubytek ludności wiejskiej. W związku z tym zwiększał się udział ludności miejskiej w całej populacji (z 50,4\% w 1950 r. do 64,3\% w 1988 r.). Wiązało się to w szczególności z dynamicznym rozwojem przemysłu i budownictwa mieszkaniowego w miastach. Zauważmy przy tym, że ludność województwa rozwijała się wolniej, aniżeli ludność całego kraju, o czym świadczy obniżenie udziału mieszkańców województwa $\mathrm{w}$ zaludnieniu Polski (z 8,7\% w 1950 r. do 7,1\% w 1988 r.).

Na początku okresu powojennego na sytuację demograficzną województwa łódzkiego istotny wpływ wywarł jego udział w zaludnianiu Ziem Odzyskanych. W latach 1945-1947 z województwa wyjechało tam około 380 tys. osób (Olejnik 2009). $\mathrm{Z}$ danych spisu ludności z 3 grudnia $1950 \mathrm{r}$. wynika, że spośród przedwojennych mieszkańców województwa łódzkiego do różnych regionów kraju przesiedliło się ogółem 362 tys. osób ${ }^{5}$. W tym samym czasie w województwie łódzkim zamieszkało 112,1 tys. osób, które przed wojną przebywały poza jego granicami lub w poza Polską .

\section{Przemiany ludnościowe w Lodzi w latach 1946-1988}

W latach 1945-1988 rozwój demograficzny Łodzi cechował trend rosnący, który bardzo dobrze aproksymuje dodatnia funkcja potęgowa. Liczba mieszkańców miasta wzrosła wówczas z 502,5 tys. do 851,7 tys., czyli o 349, 2 tys. (Dzieciuchowicz 2014). Tak dynamiczny wzrost wynikał z szybkiej odbudowy niezbyt dużych zniszczeń wojennych, znacznych inkorporacji terenów podmiejskich w latach 1945 i 1988, długotrwałego

\footnotetext{
${ }^{5} \mathrm{Z}$ czego do woj. wrocławskiego 84 tys., szczecińskiego 47 tys., koszalińskiego 34 tys. i Łodzi 81 tys.

${ }^{6} \mathrm{Z}$ tego z ZSRR (głównie z Kresów) 27 tys., Warszawy 14 tys., Łodzi 13 tys., woj. kieleckiego 10 tys., Francji 3 tys. (reemigranci).
} 
prężnego wzrostu gospodarczego oraz osiągnięcia przez miasto rangi dużego ośrodka naukowo-kulturalnego. Tempo wzrostu demograficznego Łodzi było wyjątkowo wysokie w 1945 r. dzięki olbrzymiemu napływowi ludności. Obniżyło się znacz- nie w latach 50., z uwagi na prowadzoną wówczas politykę deglomeracyjną oraz w latach 80 . wskutek ostrych konfliktów społeczno-politycznych i głębokiego regresu gospodarczego.

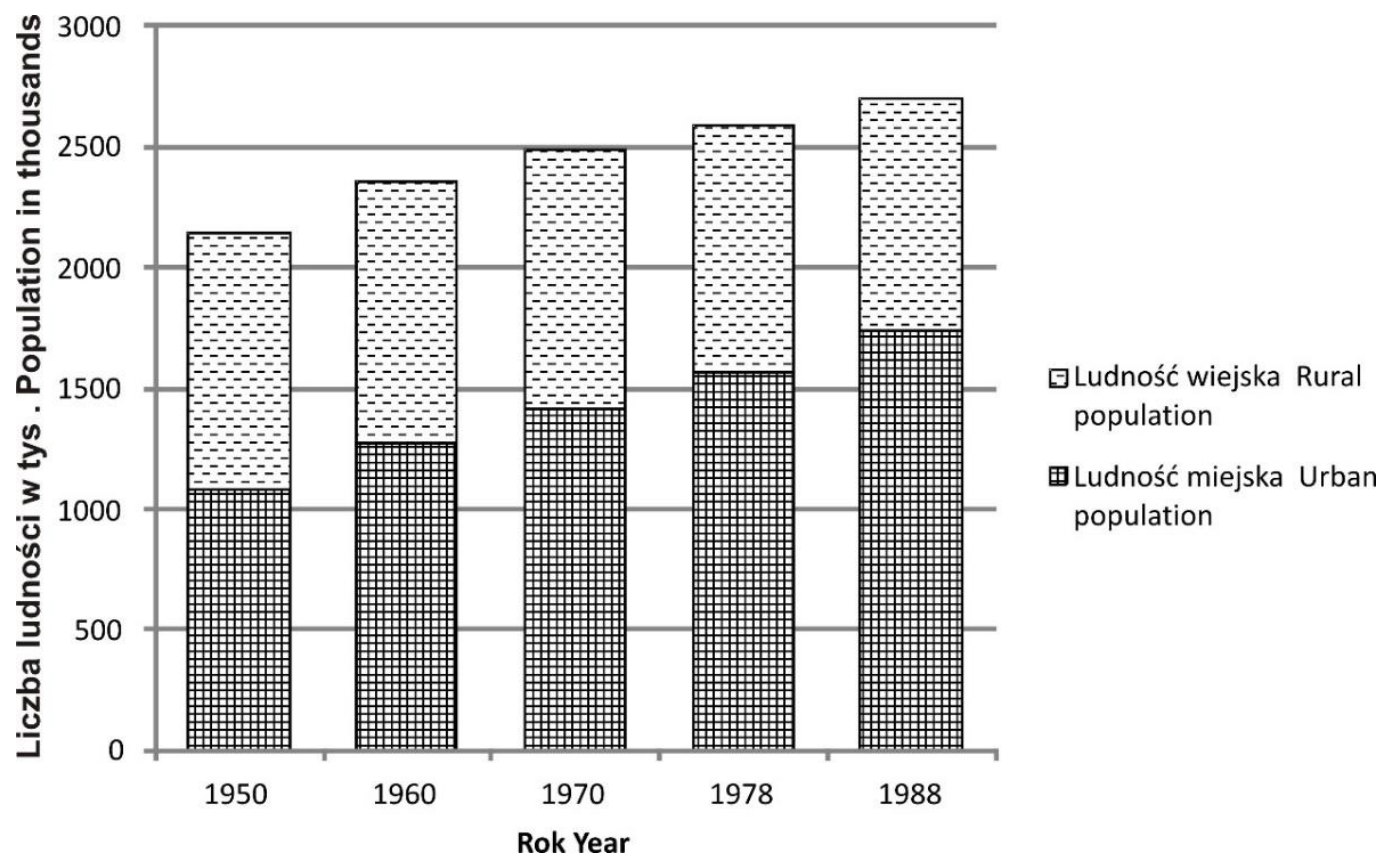

Rys. 4. Rozwój ludności województwa łódzkiego w latach 1950-1988 (w granicach województwa w dniu 01.01.1999 r.) (za: Gawryszewski 2005)

Development of the population of the Łódź Voivodeship, 1950-1988 (in voivodeship boundaries of 01.01.1999) (after: Gawryszewski 2005)

Tabela 6

Rozwój ludności województwa łódzkiego w latach 1950-1988 (w granicach województwa z dnia 01.01.1999 r.) (za: Gawryszewski 2005)

Development of the population of the Lódź Voivodeship, 1950-1988 (in voivodeship boundaries from 01.01.1999) (after: Gawryszewski 2005)

\begin{tabular}{|c|c|c|c|c|c|c|}
\hline \multirow{2}{*}{$\begin{array}{l}\text { Lata } \\
\text { Year }\end{array}$} & \multirow{2}{*}{$\begin{array}{l}\text { Ludność ogółem } \\
\text { w tys. } \\
\text { Total population } \\
\text { in thousands }\end{array}$} & \multirow{2}{*}{$\begin{array}{l}\text { Udział w zaludnie- } \\
\text { niu kraju } \% \\
\text { Share in populating } \\
\text { the country } \%\end{array}$} & \multicolumn{2}{|c|}{$\begin{array}{l}\text { Ludność miejska } \\
\text { Urban population }\end{array}$} & \multicolumn{2}{|c|}{$\begin{array}{l}\text { Ludność wiejska } \\
\text { Rural population }\end{array}$} \\
\hline & & & $\begin{array}{l}\text { tys. } \\
\text { in thousands }\end{array}$ & $\%$ & $\begin{array}{c}\text { tys. } \\
\text { in thousands }\end{array}$ & $\%$ \\
\hline 1950 & 2140,8 & 8,7 & 1079,9 & 50,4 & 1060,8 & 49,6 \\
\hline 1960 & 2361,0 & 8,0 & 1271,2 & 53,8 & 1089,7 & 46,2 \\
\hline 1970 & 2486,5 & 7,6 & 1414,8 & 56,9 & 1071,7 & 43,1 \\
\hline 1978 & 2592,7 & 7,4 & 1570,6 & 60,6 & 1022,1 & 39,4 \\
\hline 1988 & 2703,7 & 7,1 & 1737,1 & 64,3 & 966,6 & 35,7 \\
\hline
\end{tabular}

Do zjawisk demograficznych szczególnie charakterystycznych dla Łodzi w latach 19451988 należy zaliczyć wielki powojenny wyż demograficzny i późniejsze gwałtowne osłabienie dynamiki rozwoju ludności, a następnie pojawienie się echa demograficznego (Dzieciuchowicz 2014). Na początku tego okresu trwały wyjątkowo intensywne różnokierunkowe migracje, których główną składową stał się ograniczany administracyjnie napływ ludności ze wsi. Dużą dynamiką wyróżniały się poszczególne składniki ruchu naturalnego. Natężenie małżeństw stopniowo malało, podobnie jak rodność i płodność kobiet oraz dzietność, ale równocześnie wzrastało natężenie rozwodów. Wraz ze wzrostem wykształcenia i aktywności zawodowej upowszechniał się model małej 
rodziny. Poziom umieralności, zdeterminowany zarówno poprawą warunków życia, jak i strukturą demograficzną, najpierw stopniowo obniżał się, aby następnie wzrastać. W połowie lat 80 . zawężona reprodukcja ludności stała się symptomem drugiego przejścia demograficznego. Przekształcenia struktury demograficznej mieszkańców miasta znalazły wyraz w szczególności w postępującym starzeniu demograficznym. Tymczasem przemiany struktury społeczno-zawodowej ludności pod wpływem uprzemysłowienia były związane z dynamicznym wzrostem poziomu wykształcenia ludności, a także trwałą dominacją osób utrzymujących się z pracy w przemyśle. Z kolei, z procesem starzenia demograficznego łączył się wzrost udziału utrzymujących się ze źródeł niezarobkowych, głównie rent i emerytur.

Ogromne straty ludnościowe Łodzi podczas II wojny światowej były zbieżne z głębokimi przemianami jej struktury narodowościowej i wyznaniowej. Już na początku okresu powojennego w samej Łodzi doszło do niemal pełnego ujednolicenia obydwu tych struktur (Dzieciuchowicz 2014). Wynikało to przede wszystkim z dokonanej przez okupanta niemieckiego całkowitej eksterminacji Żydów oraz ucieczki pod koniec wojny dużej części Niemców i późniejszej repatriacji większości pozostałych do Niemiec. W maju 1945 r. w strukturze narodowościowej mieszkańców Łodzi bardzo silnie dominowali Polacy $(89,9 \%)$, choć na terenie miasta znajdowało się wtedy jeszcze około 33 tys. Niemców (7,8\%), a liczba Żydów wskutek imigracji wzrosła do około 6 tys. (1,5\%). Ponadto w mieście znajdowało się również 1,7 tys. Rosjan $(0,4 \%)$ i tyle samo innych mniejszości narodowościowych. Później, aż do końca lat 80. następował dalszy wzrost homogeniczności struktury wyznaniowej łodzian. W latach 1948-1949 katolicy stanowili aż 94,5\% ogółu ludności miasta, ewangelicy 3,2\%, a Żydzi (podobnie jak przedstawiciele pozostałych wyznań) jedynie $1,1 \%$.

\section{Przemiany ludnościowe w województwie lódzkim (bez Lodzi) w latach 1946-1975}

Specyficzny był rozwój i przemiany strukturalne ludności województwa łódzkiego w latach 1945-1975, formalnie funkcjonującego wtedy bez Łodzi. Początkowo liczba jego mieszkańców zmniejszała się, wskutek odpływu części ludności na Ziemie Zachodnie i Północne oraz do dużych miast i rejonów uprzemysławianych. Od $1950 \mathrm{r}$. notowano powolny wzrost demograficzny województwa. W latach 1946-1973 liczba jego mieszkańców wzrosła z 1518 tys. do 1674 tys., a więc o 156 tys. (o 10,3\%). Niewysokie tempo tego wzrostu wynikało zarówno z niskiego przyrostu naturalnego, jak i ujemnego salda migracji. Przyrost ludności wystąpił przy tym w miastach, natomiast na wsi zaznaczył się jej niewielki ubytek. Największy wzrost ludności obserwuje się w takich ośrodkach miejskich jak Zgierz, Piotrków Trybunalski, Zduńska Wola i Pabianice, a także $\mathrm{w}$ powiecie ziemskim łódzkim.

Równocześnie znacznym zmianom ulegał ruch naturalny ludności województwa. Wysokie natężenie urodzeń utrzymywało się do połowy lat 50. (25,8\% w 1955 r.), po czym następował jego powolny spadek $(15,9 \%)$, aż do początku lat 70 ., gdy tendencja ta uległa odwróceniu $(17,4 \%$ ), dzięki korzystnej polityce społecznej i wchodzeniu w wiek rozrodczy roczników powojennego wyżu demograficznego (rys. 5). Do połowy lat 60. wraz z poprawą warunków życia obniżał się ogólny poziomu umieralności (z 12,7\%o w 1950 r. do 8\%o w 1965 r.). Jednakże w następnych latach, pod wpływem postępującego starzenia demograficznego poziom ten zaczął powoli wzrastać $(9,8 \%$ w 1973 r.). Należy przy tym podkreślić gwałtowne obniżenie umieralności niemowląt. Liczba zgonów niemowląt $\mathrm{w}$ przeliczeniu na 1000 urodzeń żywych zmalała ze 123 w 1949 r. do 27 w 1973 r. Tymczasem, wskutek wspomnianych wcześniej zmian rodności i umieralności, przyrost naturalny wykazywał tendencję rosnąco-malejącą. Jednocześnie w latach 1955-1973 w skali całego województwa $\mathrm{z}$ reguły występowało ujemne saldo migracji (-6,4\%o w 1973 r.) (rys. 6). Doszło do tego wskutek wysokiego ubytku migracyjnego na wsi (-11,2 \%o w 1973 r.), przewyższającego w liczbach bezwzględnych dodatnie saldo migracji $\mathrm{w}$ miastach $(+4,8 \%$ o w 1973 r.).

W okresie 1945-1975 rozwój demograficzny, a także sam ruch naturalny i migracyjny wywierały znaczny wpływ na strukturę płci i wieku mieszkańców województwa łódzkiego. Jednakże bardzo silna feminizacja ludności województwa była przede wszystkim jednym $\mathrm{z}$ następstw demograficznych II wojny światowej. W 1946 r. na 100 mężczyzn przypadało tam aż 114 kobiet. Później m.in. pod wpływem wysokiego poziomu rodności, współczynnik feminizacji ludności województwa systematycznie malał, aby w połowie lat 60 . osiągnąć stopień umiarkowany (1967 r.: 106). Niemniej jednak aż do końca analizowanego okresu przewyższał on poziom przedwojenny. Wskutek silnego odpływu migracyjnego młodych kobiet z obszarów wiejskich do miast, feminizacja ludności miejskiej była przy tym wyższa, aniżeli wśród mieszkańców wsi. 


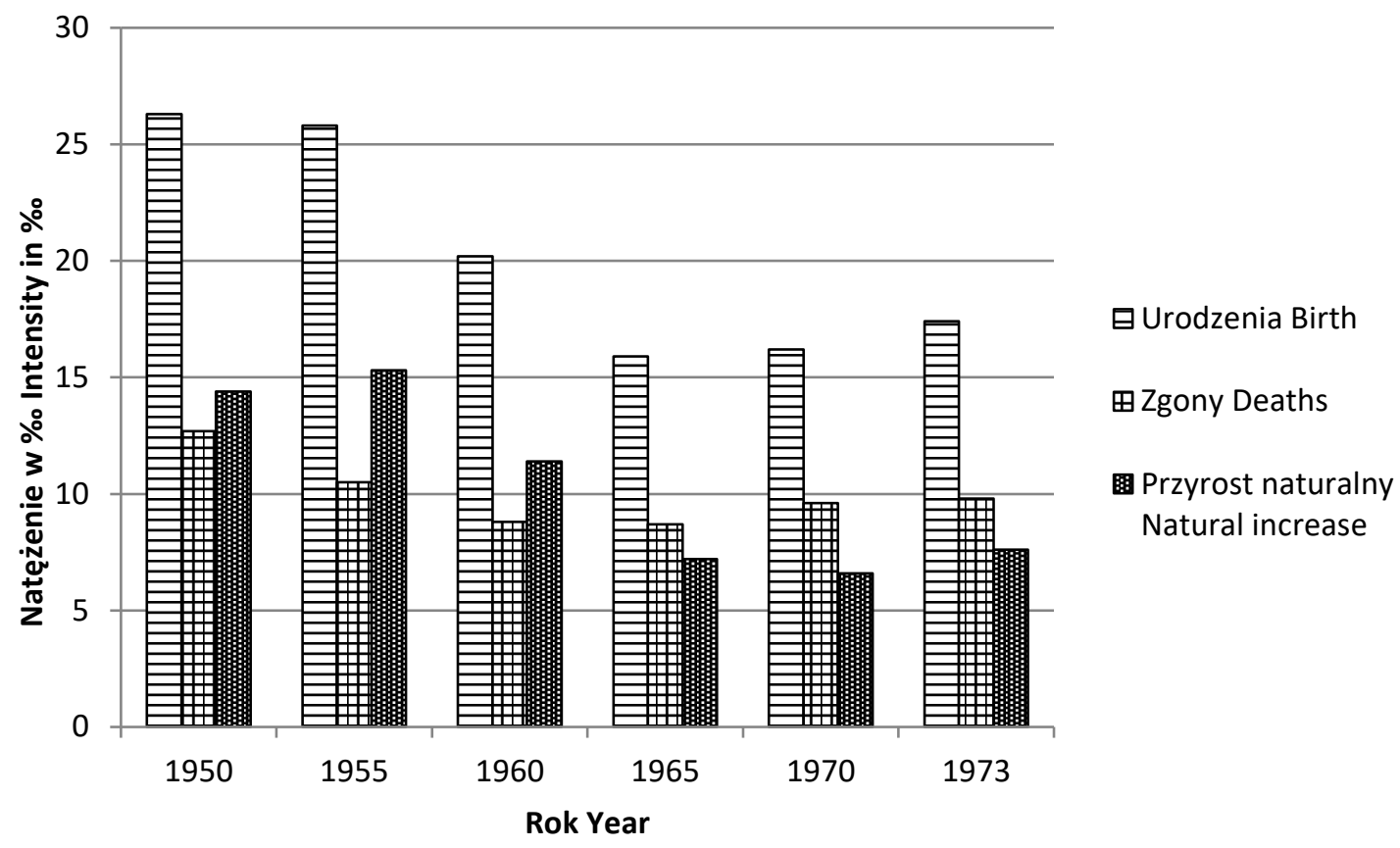

Rys. 5. Przyrost naturalny w województwie łódzkim w latach 1950-1973

(za: Województwo łódzkie w XXX-leciu PRL 1974)

Natural movement in the Łódź Voivodeship, 1950-1973

(after: Województwo łódzkie w XXX-leciu PRL 1974)

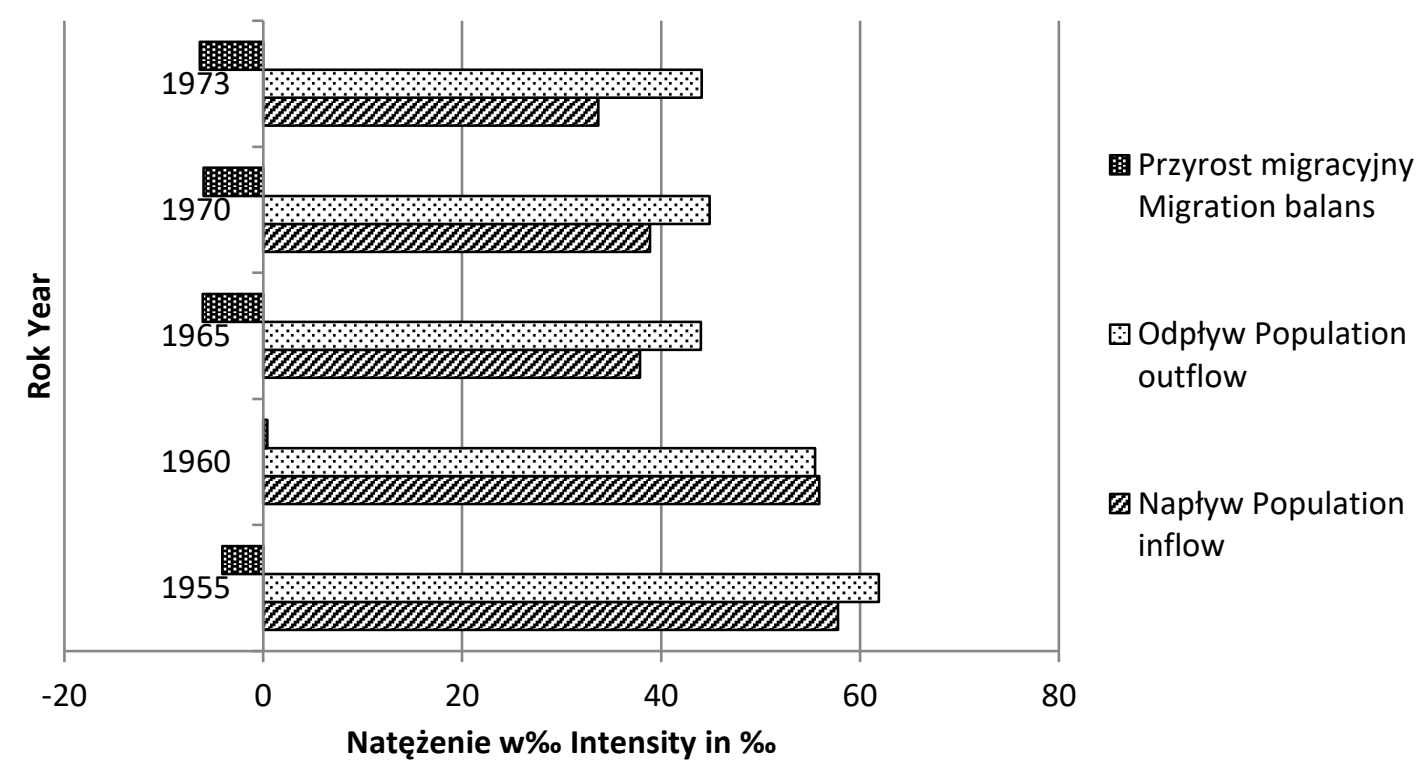

Rys. 6. Przyrost migracyjny w województwie łódzkim w latach 1955-1973

(za: Województwo łódzkie w XXX-leciu PRL 1974)

Migration increase in the Łódź Voivodeship, 1955-1973

(after: Województwo łódzkie w XXX-leciu PRL 1974)

Równolegle następowały istotne przekształcenia struktury wieku ludności województwa, oddziałujące na regionalną politykę społeczną i gospodarczą. Polegały one przede wszystkim na gwałtownym spadku (do 25,2\% w 1970 r.), początkowo wysokiego $(31,7 \%$ w 1950 r.) udziału grupy wieku 0-15 lat i wzroście zrazu niskiego udziału grupy powyżej 60 lat (z 9,7 w 1950 r. do $15,4 \%$ w 1970 r.), przy różnokierunkowych zmianach udziału grupy wieku produkcyjnego (16-59 
lat). Wskazuje to na postępujący proces starzenia społeczeństwa województwa, zachodzący w głównej mierze na obszarach wiejskich, $\mathrm{z}$ uwagi na nasilony odpływ migracyjny młodzieży do miast.

W latach 1945-1975, w wyniku radykalnych przemian ustrojowo-politycznych i przyspieszonego rozwoju gospodarczego, głębokie przeobrażenia objęly strukturę społeczno-zawodową ludności rozpatrywanego województwa. Ich wyrazem był szybki ogólny wzrost aktywności zawodowej (55,3\% w 1970 r.) oraz zatrudnienia w gospodarce uspołecznionej poza rolnictwem, zwłaszcza w przemyśle, przy równoczesnym powolnym spadku liczby pracujących w prywatnych gospodarstwach rolnych, które jednakże nadal zatrudniały najwięcej mieszkańców województwa. O silnym rozdrobnieniu tych gospodarstw, stymulującym odpływ migracyjny, świadczy fakt, iż w 1970 r. na 100 hektarów użytków rolnych przypadało 38 osób. Dla województwa łódzkiego szczególnie charakterystyczny był rosnący (z 34,9\% w 1960 r. do 43,2\% w 1973 r.), i zarazem wyższy niż w całym kraju, udział kobiet zatrudnionych $\mathrm{w}$ gospodarce uspołecznionej. Wynikało to głównie $\mathrm{z}$ dominacji przemysłu włókienniczego i odzieżowego w strukturze gałęziowej przemysłu. Wraz ze zmianami struktury zatrudnienia wzrósł udział osób utrzymujących się głównie z pracy poza rolnictwem (z 39\% w 1950 r. do $58,5 \%$ w 1970 r.). Należy również odnotować likwidację analfabetyzmu już w pierwszych latach powojennych, a następnie dynamiczny wzrost poziomu wykształcenia ludności województwa, świadczący wymownie o jej awansie społecznym. Na szczególną uwagę zasługuje przy tym aż 4-krotny wzrost w latach 1960-1970 liczby osób z wykształceniem zasadniczym zawodowym i niepełnym średnim, a także równoczesne zwiększenie liczby ludności z wykształceniem średnim o około $75 \%$ i wyższym o ponad $50 \%$.

Przed II wojną światową na obszarze województwa łódzkiego (z wyłączeniem samej Łodzi) mniejszości narodowościowe liczyły łącznie około 260 tys. osób, tj. 12,6\% ogółu ludności (Olejnik 2009, 212). Największą z nich tworzyli Żydzi (173,3 tys.), drugą pod względem liczebności stanowili Niemcy $(75,9$ tys.). Do nielicznej grupy pozostałych mniejszości (6,8 tys.) należeli w głównej mierze Czesi i Rosjanie. Po wojnie struktura narodowościowa województwa stała się prawie jednorodna. Według spisu ludności z 14 lutego 1946 roku udział Polaków wzrósł tam do 96,7\% (1 714012 osób), choć na tym obszarze przebywało również jeszcze 58,9 tys. Niemców $(3,3 \%)$ oraz $2775(0,2 \%)$ osób należących do innych narodowości. Postępowanie weryfikacyjne lub rehabilitacyjne było prowadzone wobec 5691 osób. Po dwóch latach udział mniejszości narodowościowych obniżył się w województwie do 1,65\%. Byli to głównie Niemcy (26284) i Żydzi (1152). W następnych latach większość Niemców została wysiedlona. Niewielkie skupiska Żydów istniały nadal w Pabianicach, Piotrkowie Trybunalskim, Zgierzu, Tomaszowie Mazowieckim i Zduńskiej Woli. Nieduża grupa Rosjan (kilkadziesiąt osób) przebywała w Piotrkowie Trybunalskim. Jeszcze jesienią 1945 r. kilka tysięcy Czechów mieszkało w Zelowie, Kurowie i ich okolicach. Po ich reemigracji do Czechosłowacji w Zelowie pozostało zaledwie około 500 osób narodowości czeskiej.

Rozmieszczenie ludności województwa łódzkiego w całym rozpatrywanym okresie było bardzo nierównomierne. W końcu 1964 r. na w jego ówczesnych granicach najwięcej ludności zamieszkiwało powiaty: radomszczański (139,3 tys.), łódzki (112,9 tys.) i kutnowski (110,6 tys.) (rys. 7, 8). Tymczasem Łódź, administracyjnie tworząca odrębne województwo, skupiała wtedy aż 739,6 tys. osób. Najmniejszymi zasobami ludnościowymi, nieprzekraczającymi 50 tys. osób, cechowały się powiaty: zduńskowolski i wieruszowski. W województwie łódzkim przeważała ludność mieszkająca na wsi. Ludność miejska żyła głównie w małych ośrodkach. Do większych miast, liczących >50 tys. mieszkańców, należały: Pabianice, Piotrków Trybunalski i Tomaszów Mazowiecki. Przeciętna gęstość zaludnienia w województwie dochodziła do 97 osób $/ \mathrm{km}^{2}$. Na terenie powiatów grodzkich gęstość ta przekraczała $1000 \mathrm{osób} / \mathrm{km}^{2}$. W powiatach ziemskich gęstością wyższą od przeciętnej w województwie wyróżniały się powiaty: kutnowski, łęczycki i łódzki. Niższa gęstość cechowała powiaty o słabych glebach i dużej lesistości, często położone w rejonach przygranicznych i wzdłuż kanałów komunikacyjnych.

\section{Ludność województwa lódzkiego w latach 1989-2018}

\section{Rozwój ludności}

W odróżnieniu od poprzedniego okresu, w latach 1988-2017 rozwój ludności województwa łódzkiego (w aktualnych granicach) cechowała ogólna tendencja spadkowa, uwarunkowana przeszłością demograficzną i współczesnymi przemianami społeczno-kulturowymi. Liczba mieszkańców zmalała wówczas z 2703,7 tys. do 2476,3 tys., tj. aż o 227,4 tys. osób (o 8,4\%). Na dużą skalę tego ubytku wskazuje fakt, iż przewyższał on m.in. aktualną liczbę ludności Częstochowy lub Radomia. Depopulacja ta stanowi obecnie jeden z najważ- 
niejszych problemów demograficznych omawianego regionu. Ma bowiem negatywny wpływ na jego wzrost demograficzny wskutek ograniczenia reprodukcji ludności, a także na rozwój społecznoekonomiczny, przyczyniając się do zmniejszenia zasobów siły roboczej. Procesy depopulacyjne obejmują w Polsce także wiele innych województw. Jednakże względny ubytek ludności w latach 1995-2013, większy aniżeli w województwie łódzkim, był jedynie w województwach. opolskim i śląskim (Janiszewska 2015). Szczegółowe dane dotyczące stanu ludności województwa łódzkiego z lat 1995-2017 dowodzą odmiennych tendencji w rozwoju ludnościowym jego miast i wsi (rys. 9, 10; tab. 7).

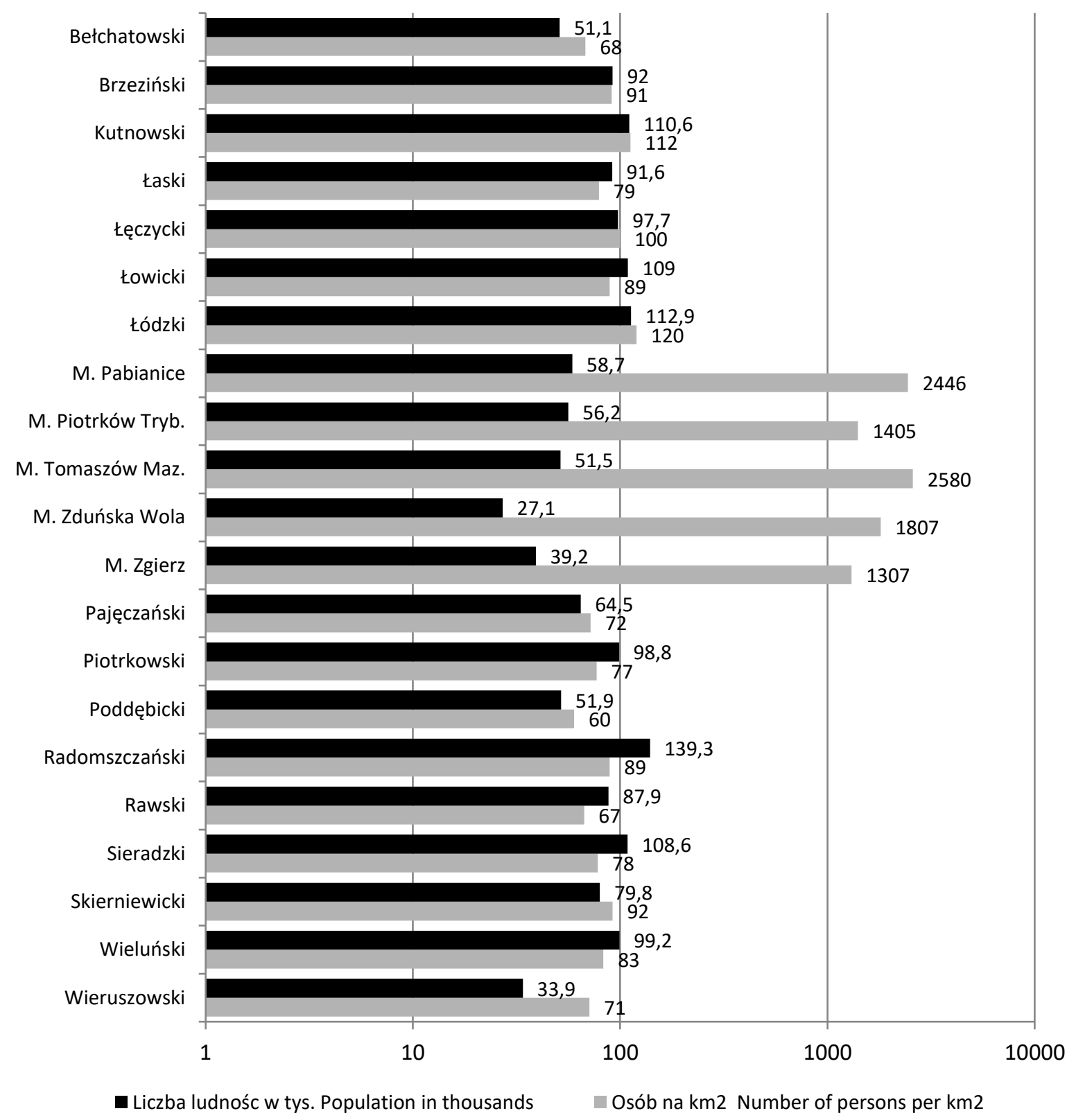

Rys. 7. Liczba ludności i gęstość zaludnienia według powiatów w województwie łódzkim w 1964 r. (wartości na osi poziomej zlogarytmowane) (za: Rocznik Statystyczny Województwa Łódzkiego 1965)

Population number and density by poviat in the Łódź Voivodeship, 1964 (values on the horizontal pivot logarithmic) (after: Rocznik Statystyczny Województwa Łódzkiego 1965) 


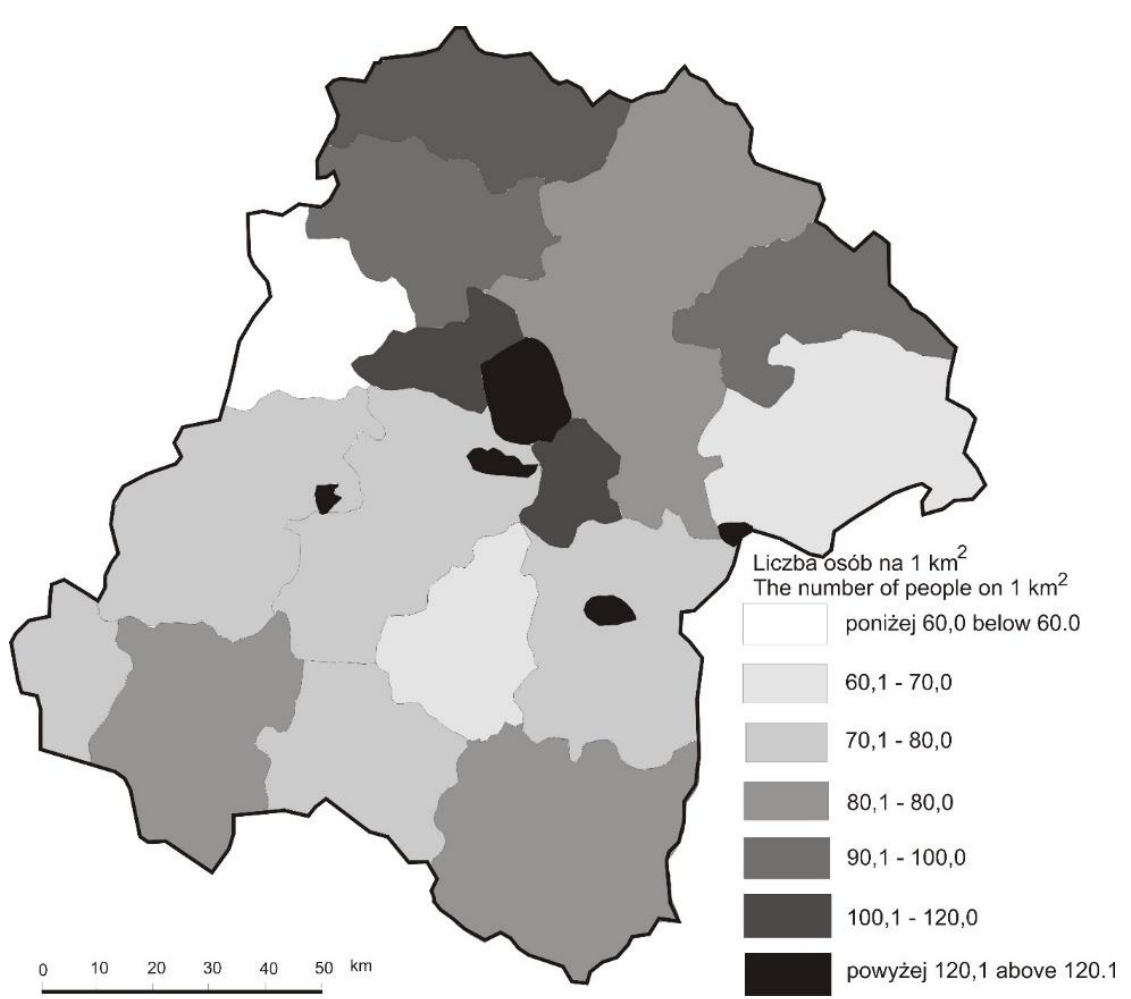

Rys. 8. Gęstość zaludnienia województwa łódzkiego w 1964 r. (za: Straszewicz 1967)

Population density of the Łódź Voivodeship, 1964 (after: Straszewicz 1967)

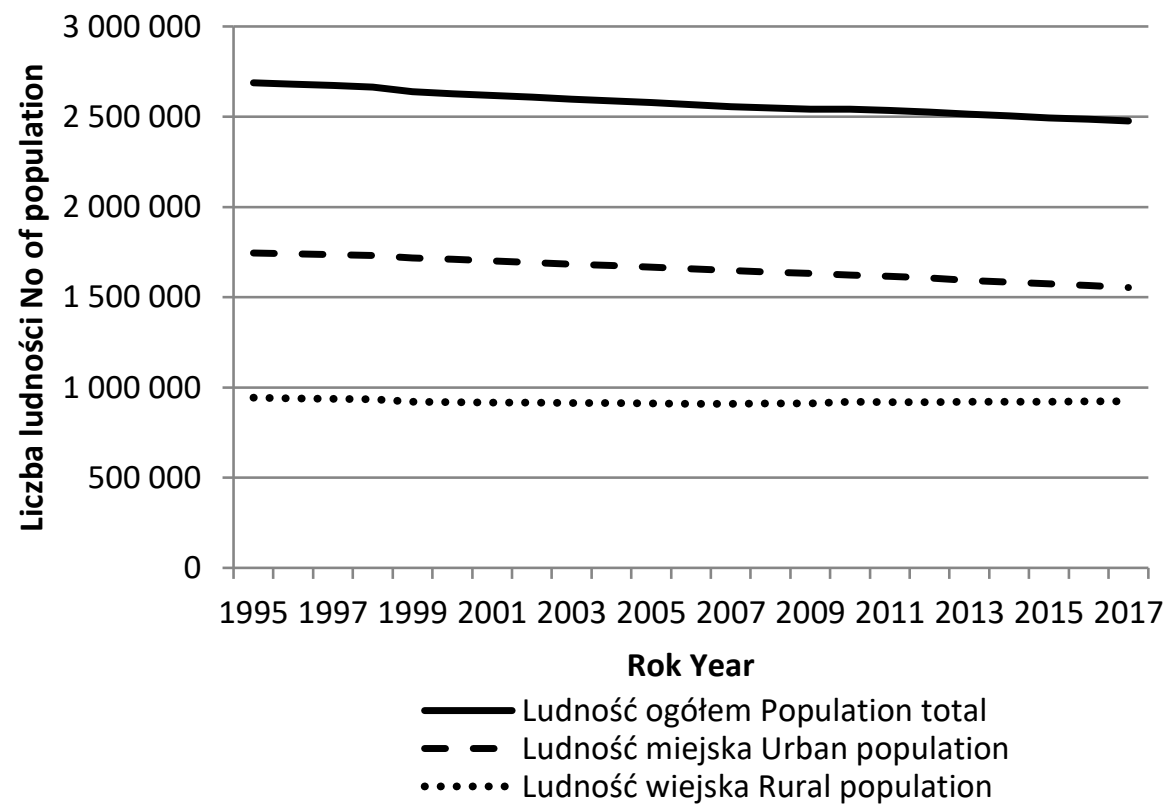

Rys. 9. Rozwój ludności województwa łódzkiego w latach 1995-2017 (za: Bank Danych Lokalnych GUS; Roczniki Demograficzne 1996-2018)

Development of the population of the Łódź Voivodeship, 1995-2017 (after: Bank Danych Lokalnych GUS; Roczniki Demograficzne (1996-2018) 


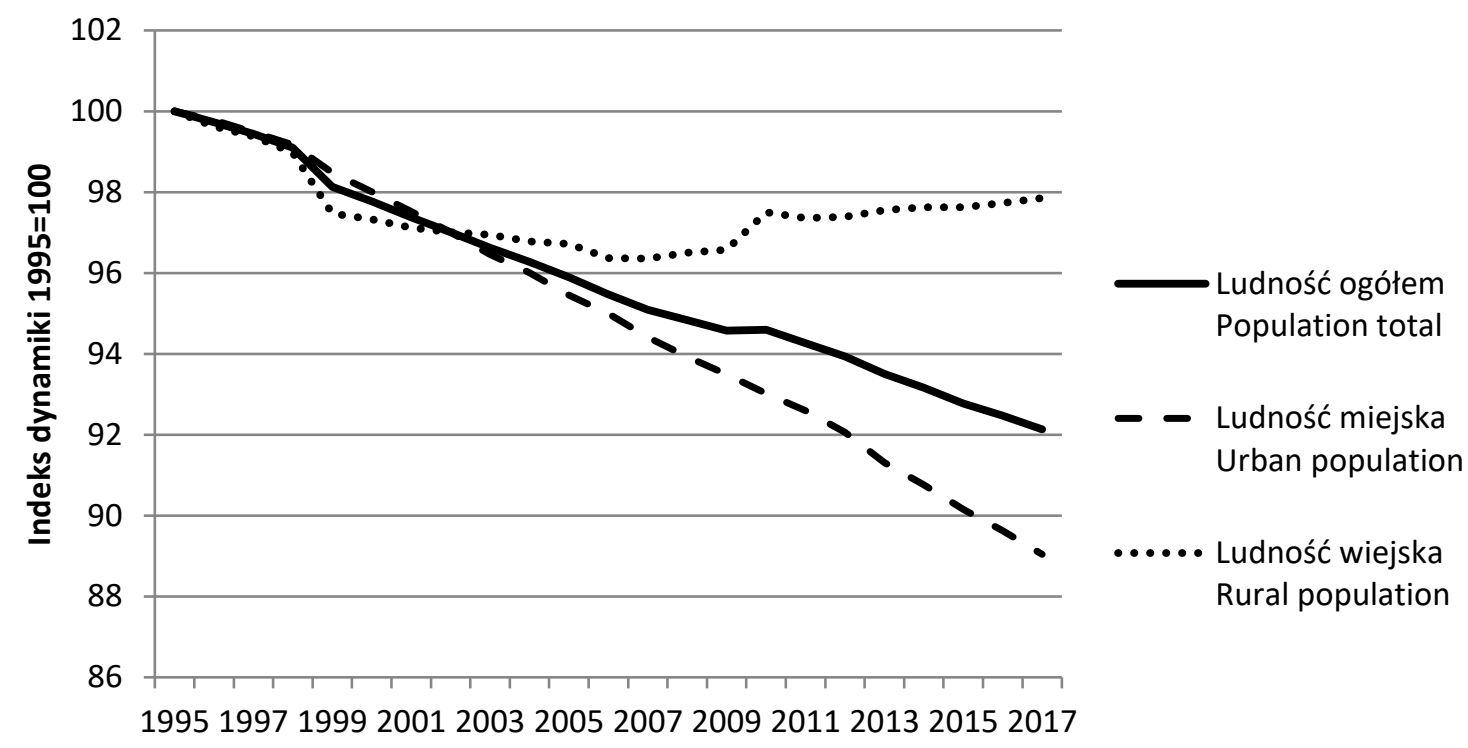

Rok Year

Rys. 10. Dynamika rozwoju ludności województwa łódzkiego w latach 1995-2017

(za: Roczniki Statystyczne Województwa Łódzkiego 1996-2018; Roczniki Demograficzne 1996-2018)

Population growth dynamics of the Łódź Voivodeship, 1995-2017

(after: Roczniki Statystyczne Województwa Lódzkiego 1996-2018; Roczniki Demograficzne 1996-2018)

Tabela 7

Rozwój ludności województwa łódzkiego w latach 1995-2017

(za: Roczniki Statystyczne Województwa Łódzkiego1995-2018; Roczniki demograficzne 1995-2019)

Development of the population of the Łódź Voivodeship, 1995-2017

(after: Roczniki Statystyczne Województwa Łódzkiego1995-2018; Roczniki demograficzne 1995-2019)

\begin{tabular}{|c|c|c|c|c|c|}
\hline \multirow{3}{*}{$\begin{array}{c}\text { Rok } \\
\text { Year }\end{array}$} & \multicolumn{3}{|c|}{$\begin{array}{c}\text { Liczba ludności w tysiącach } \\
\text { Population numbers in thousands }\end{array}$} & \multicolumn{2}{c|}{$\begin{array}{c}\text { Udział procentowy } \\
\text { Share \% }\end{array}$} \\
\cline { 2 - 6 } & $\begin{array}{c}\text { Ogółem } \\
\text { Total }\end{array}$ & $\begin{array}{c}\text { ludność } \\
\text { miejska } \\
\text { Urban } \\
\text { population }\end{array}$ & $\begin{array}{c}\text { ludność } \\
\text { wiejska } \\
\text { Rural } \\
\text { population }\end{array}$ & $\begin{array}{c}\text { ludność } \\
\text { miejska } \\
\text { Urban } \\
\text { population }\end{array}$ & $\begin{array}{c}\text { ludność } \\
\text { wiejska } \\
\text { Rural } \\
\text { population }\end{array}$ \\
\hline 1995 & 2687,8 & 1744,6 & 943,2 & 64,9 & 35,1 \\
\hline 2000 & 2627,8 & 1709,9 & 917,9 & 65,1 & 34,9 \\
\hline 2005 & 2577,5 & 1665,3 & 912,2 & 64,6 & 35,4 \\
\hline 2010 & 2542,4 & 1622,8 & 919,6 & 63,8 & 36,2 \\
\hline 2015 & 2493,6 & 1572,9 & 920,7 & 63,1 & 36,9 \\
\hline 2016 & 2485,3 & 1563,6 & 921,7 & 62,9 & 37,1 \\
\hline 2017 & 2476,3 & 1554,3 & 922,9 & 62,7 & 37,3 \\
\hline
\end{tabular}

Ludność miejską wyróżniał silny trend spadkowy. Jej liczba zmalała wtedy o 183,7 tys. $(10,6 \%)$. W tym samym czasie potencjał ludnościowy wsi podlegał niewielkim, różnokierunkowym zmianom. Ubytek ludności miejskiej miał charakter ciągły i następował bardzo dynamicznie. Tymczasem wśród mieszkańców wsi do połowy analizowanego okresu obserwowano silną tendencję spadkową, a później słaby trend wzrostowy. Wskazane różnice w rozwoju ludności miast i wsi w dużej mierze są spowodowane odpływem migracyjnym z dużych miast do ich stref podmiejskich. W szczególności dotyczy to Łodzi. Dodajmy, iż w latach 1995-2017 obniżył się udział ludności województwa łódzkiego w zasobach ludnościowych Polski z 7,0\% do 6,4\%. Świadczy to o wolniejszym rozwoju ludnościowym województwa aniżeli całego kraju.

Zmienną w czasie długookresową dynamikę wzrostu demograficznego w województwie łódz- 
kim w okresie 1995-2017 dobrze odzwierciedla przyrost rzeczywisty ludności. Zmiany jego natężenia, przy ogólnej tendencji spadkowej, następowały nieregularnie (rys. 11; tab. 8). Związane z tym były duże odchylenia od wspomnianej tendencji. Minimalną ujemną wartość, równą $-2,8 \%$, współczynnik przyrostu rzeczywistego, miał w 2009 roku, a maksymalną, wynoszącą aż -4, 5\%o, w 2013 roku. Średnie natężenie tego przyrostu osiągnęło $-3,6 \%$.

W całym analizowanym okresie o wielkości ujemnego przyrostu rzeczywistego ludności decy- dował bardzo duży ubytek naturalny. Obszar zmienności współczynnika przyrostu naturalnego zawierał się w przedziale od $-2,2 \%$ (rok 2010) do -3, 6\%o (1999 rok), a jego przeciętna wartość wynosiła $-3,0 \%$. Ubytek naturalny został ukształtowany w warunkach niewielkiego natężenia zawieranych małżeństw, wysokiej ogólnej umieralności (zbieżnej z bardzo niskim natężeniem zgonów niemowląt), oraz dość niskiej rodności, płodności i dzietności.

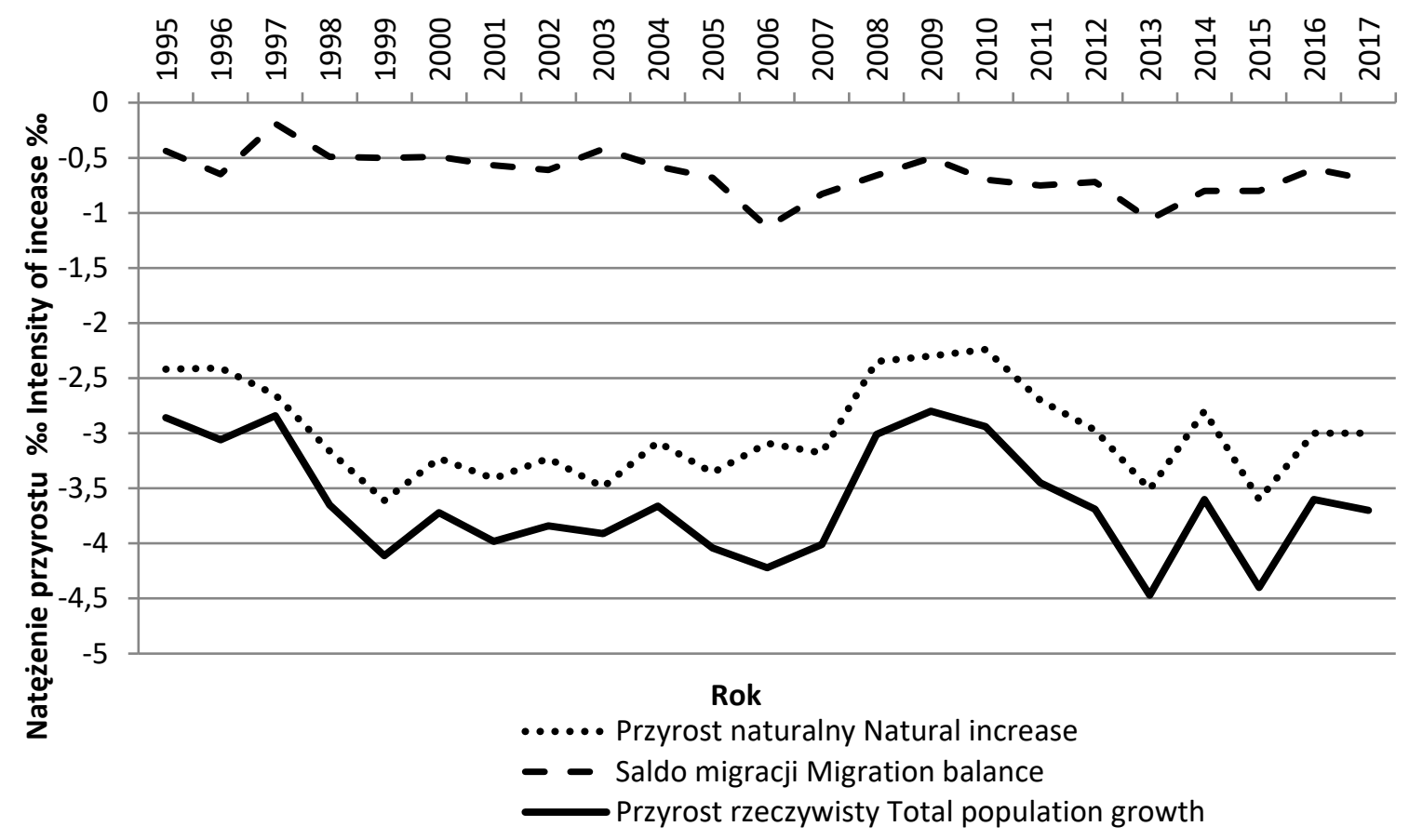

Rys. 11. Przyrost rzeczywisty ludności województwa łódzkiego w latach 1995-2017

(za: Roczniki Statystyczne Województwa Łódzkiego 1996-2018; Roczniki Demograficzne 1996-2018)

Population growth in Łódź Voivodeship, 1995-2017

(after: Roczniki Statystyczne Województwa Łódzkiego 1996-2018; Roczniki Demograficzne 1996-2018)

Tabela 8

Zmiany demograficzne w województwie łódzkim w latach 1995-2017 (w \%) (za: Roczniki Statystyczne Województwa Łódzkiego 1996-2018; Roczniki Demograficzne 1996-2018)

Demographic changes in the Łódź Voivodeship, 1995-2017 (in \%o)

(after: Roczniki Statystyczne Województwa Łódzkiego 1996-2018; Roczniki Demograficzne 1996-2018)

\begin{tabular}{|c|c|c|c|c|c|c|}
\hline $\begin{array}{c}\text { Rok } \\
\text { Year }\end{array}$ & $\begin{array}{c}\text { Małżeństwa } \\
\text { Marriages }\end{array}$ & $\begin{array}{c}\text { Urodzenia } \\
\text { żywe } \\
\text { Live births }\end{array}$ & $\begin{array}{c}\text { Zgony } \\
\text { Deaths }\end{array}$ & $\begin{array}{c}\text { Przyrost } \\
\text { naturalny } \\
\text { Natural increase }\end{array}$ & $\begin{array}{c}\text { Saldo } \\
\text { migracji } \\
\text { Net migration }\end{array}$ & $\begin{array}{c}\text { Przyrost } \\
\text { rzeczywisty } \\
\text { Real increase }\end{array}$ \\
\hline 1995 & 5,4 & 10,1 & 12,6 & $-2,4$ & $-0,4$ & $-2,8$ \\
\hline 2000 & 5,3 & 8,9 & 12,1 & $-3,2$ & $-0,5$ & $-3,7$ \\
\hline 2005 & 5,2 & 8,7 & 12,1 & $-3,4$ & $-0,7$ & $-4,1$ \\
\hline 2010 & 5,7 & 10,0 & 12,3 & $-2,2$ & $-0,7$ & $-2,9$ \\
\hline 2015 & 4,6 & 8,9 & 12,5 & $-3,6$ & $-0,8$ & $-4,4$ \\
\hline 2016 & 4,7 & 9,2 & 12,1 & $-3,0$ & $-0,6$ & $-3,6$ \\
\hline 2017 & 4,7 & 9,6 & 12,6 & $-3,0$ & $-0,7$ & $-3,7$ \\
\hline
\end{tabular}


Do najczęstszych przyczyn zgonów w województwie łódzkim - podobnie jak w całym kraju w 2016 r. należały choroby układu krążenia $(40,4 \%)$ i nowotwory $(25,2 \%)$. Łącznie tylko te dwie przyczyny odpowiadały za prawie $2 / 3(65,6 \%)$ wszystkich zgonów. Dużo mniejsze znaczenie miały choroby układu oddechowego $(6,4 \%)$, urazy i zatrucia $(5,3 \%)$ oraz choroby układu trawiennego $(4,7 \%)$. $\mathrm{W}$ całym regionie zróżnicowanie przestrzenne umieralności zależało od stopnia koncentracji ludności i przemysłu, poziomu urbanizacji, warunków ekologicznych i poziomu opieki zdrowotnej (Dzieciuchowicz 1998). W ostatnich latach poziomu przyrostu naturalnego nie podniosła wyraźnie prowadzona w Polsce polityka społeczna, w tym realizacja programu 500+. Chociaż w latach 2015-2017 nieznacznie wzrosło natężenie urodzeń (z 8,9\%o do $9,6 \%$ ), to przyrost naturalny stale pozostawał ujemny. Dodajmy, iż w pierwszej połowie 2018 roku urodziło się mniej dzieci (11571), niż w pierwszym półroczu roku poprzedniego.

Odrębną sekwencją zmian w omawianym okresie odznaczał się ujemny przyrost migracyjny. Przy słabo zarysowanej ogólnej tendencji spadkowej i niewielkich oscylacjach (od $-0,19 \%$ do $-1,13 \%$ ) średnie natężenie salda migracji było bardzo niskie $(-0,65 \%)$.

\section{Struktura demograficzna}

Wraz z opisanym wyżej spadkiem liczby ludności województwa łodzkiego w okresie 19892017, następowały zmiany struktury tej populacji. Jej współczynnik feminizacji wzrósł w niewielkim stopniu, gdyż ze 109 kobiet na 100 mężczyzn w 1988 r. do 110 w 2017 r. Warto jednak zauważyć, że dane spisowe z lat 2002 i 2011 wskazują na duże różnice proporcji płci w układzie miasto-wieś. Wyższy początkowo współczynnik feminizacji ludności miejskiej później jeszcze bardziej wzrósł (do 115), natomiast jego niższy poziom na wsi pozostawał ustabilizowany (101).

Piramida płci i wieku (rys. 12) opracowana na podstawie danych NSP 2011 uwidacznia charakterystyczną zależność proporcji płci od wieku. Nadwyżka liczby mężczyzn nad liczbą kobiet cechowała dzieci i także młodsze roczniki dorosłych. W wieku 0-4 lat na 100 chłopców przypadało tylko 95 dziewczynek, co było konsekwencją częstszych urodzeń chłopców niż dziewcząt. Z kolei, ze względu na wyższą umieralność mężczyzn, ich nadwyżka malała w coraz starszych grupach wiekowych. Do wyrównania proporcji płci doszło w grupie wieku 40-44 lat. Natomiast przewaga liczebna kobiet nad mężczyznami zaznaczała się coraz wyraźniej, począwszy od przedziału 45-49 lat, w którym na 100 mężczyzn przypadały 102 kobiety. Na przykład w grupie 70-74 lat na 100 mężczyzn przypadało już 157 kobiet, a w grupie 80 lat i więcej aż 253 kobiety.

Zmiany w strukturze ludności województwa w latach 1995-2017, rozpatrywane według ekonomicznych grup wieku ${ }^{7}$, znalazły swój wyraz głównie $\mathrm{w}$ spadku udziału osób $\mathrm{w}$ wieku przedprodukcyjnym (z $24,8 \%$ do $16,9 \%$ ), przy równoczesnym wzroście tych w wieku poprodukcyjnym (z 16,4\% do 23,1\%) (rys. 13; tab. 9). Zmiany te świadczą o dużej dynamice procesu starzenia demograficznego. Porównując dane spisów z lat 2002 i 2011, można zauważyć, iż proces ten objął równocześnie grupę wieku produkcyjnego, w której zmniejszył się udział osób w wieku mobilnym (1844 lat). W okresie międzyspisowym odsetek ludności $\mathrm{w}$ wieku poprodukcyjnym wzrósł jednak wyraźnie w miastach (z 16,3\% do 19,5\%), natomiast nieznacznie obniżył się na wsi (z 18,5\% do $18,1 \%)$. W rezultacie w 2011 r. stopień zaawansowania starzenia się ludności miast był większy aniżeli wsi. Równocześnie nastąpił znaczny spadek wskaźnika obciążenia demograficznego ludności wiejskiej. Dodajmy, iż w latach 1995-2017 na przemiany struktury wieku ludności województwa istotny wpływ miał znaczny wzrost (dotychczas najniższego wśród województw) zarówno przeciętnego dalszego trwania życia mężczyzn (67,6 do 71,9 lat), jak i kobiet (76,4 do 80,8 lat). Dane te dowodzą rosnącej nadumieralności mężczyzn w stosunku do kobiet.

\section{Struktura społeczno-ekonomiczna}

Korzystnie o stratyfikacji społecznej w województwie łódzkim świadczy struktura wykształcenia jego mieszkańców. Z danych spisu z 2011 r. wynika, że co najmniej średnie wykształcenie miała prawie połowa osób $\mathrm{w}$ wieku 13 lat i więcej $(49,3 \%)$, dla których ustalono poziom wykształcenia (tab. 10). Warto przy tym podkreślić, iż odsetek osób z wykształceniem wyższym osiągnął aż $16,2 \%$, dzięki czemu pod tym względem województwo znalazło się na 7 pozycji wśród ogółu województw. Zwraca też uwagę duży udział osób $\mathrm{z}$ wykształceniem zasadniczym zawodowym (20,2\%). W okresie międzyspisowym 2002-2011

\footnotetext{
${ }^{7}$ Wiek przedprodukcyjny 0-17 lat; wiek produkcyjny - mężczyźni 18-64 lata, kobiety 18-59 lat; wiek poprodukcyjny mężczyźni 65 lat i więcej, kobiety 60 lat i więcej.
} 
wyraźnie wzrósł odsetek osób z wykształceniem wyższym (o 6,9\%) i równocześnie znacznie zmalały odsetki osób z wykształceniem podstawowym i gimnazjalnym (o 6,2\%), a w mniejszym stopniu także osób bez wykształcenia (o 2,9\%), wśród których przeważali ,seniorzy” w wieku 65 lat $\mathrm{i}$ więcej.

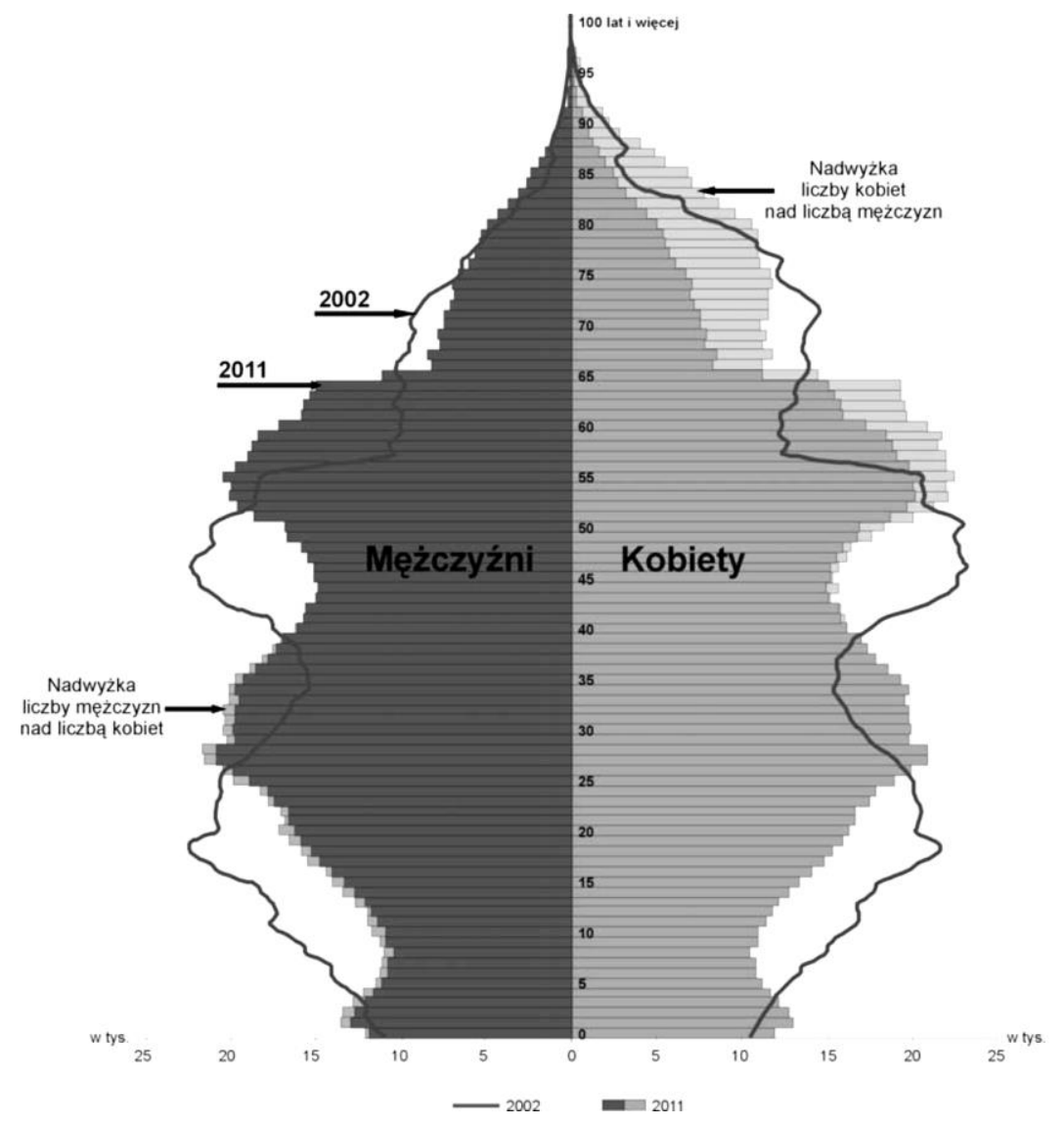

Rys. 12. Ludność województwa łódzkiego wg płci i wieku w latach 2002 i 2011 (za: Narodowy Spis Powszechny 2002, 2011)

Population of the Łódź Voivodeship by sex and age, 2002 and 2011 (after: Narodowy Spis Powszechny 2002, 2011)

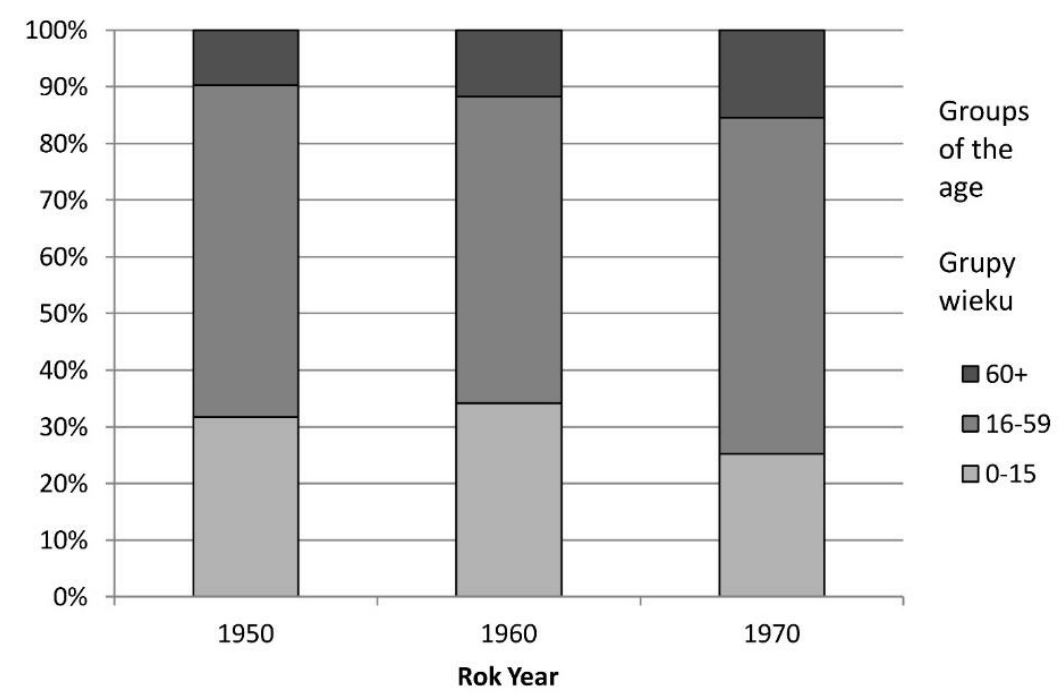

Rys. 13. Ludność województwa łódzkiego według biologicznych grup wieku w latach 1995-2016 (za: Roczniki Statystyczne Województwa Łódzkiego 1996-2018)

Population of the Łódź Voivodeship by biological groups of age, 1995-2016 (after: Roczniki Statystyczne Województwa Łódzkiego 1996-2018) 
Ludność woj. łódzkiego według ekonomicznych grup wieku w latach 1995-2016 (stan 31 XII)

(za: Roczniki Statystyczne Województwa Łódzkiego 1996-2017)

Population of the Łódź Voivodeship by economic age groups, 1995-2016 (state 31 December) (after: Roczniki Statystyczne Województwa Łódzkiego 1996-2017)

\begin{tabular}{|c|c|c|c|c|}
\hline \multirow{2}{*}{$\begin{array}{l}\text { Rok } \\
\text { Year }\end{array}$} & \multirow{2}{*}{$\begin{array}{l}\text { Ludność ogółem } \\
\text { Total population }\end{array}$} & \multicolumn{3}{|c|}{$\begin{array}{l}\text { Grupy wieku } \\
\text { Age groups }\end{array}$} \\
\hline & & $\begin{array}{l}\text { przedprodukcyjna } \\
\text { preworking }\end{array}$ & $\begin{array}{l}\text { produkcyjna } \\
\text { working }\end{array}$ & $\begin{array}{l}\text { poprodukcyjna } \\
\text { postworking }\end{array}$ \\
\hline \multicolumn{5}{|c|}{ w tysiącach in thousands } \\
\hline 1995 & 2687,8 & 666,9 & 1579,8 & 441,1 \\
\hline 2000 & 2627,8 & 579,4 & 1603,7 & 444,7 \\
\hline 2005 & 2577,5 & 486,5 & 1646,4 & 444,6 \\
\hline 2010 & 2542,4 & 444,4 & 1620,8 & 477,2 \\
\hline 2015 & 2493,6 & 418,6 & 1530,5 & 544,5 \\
\hline 2016 & 2485,3 & 417,6 & 1508,9 & 558,8 \\
\hline 2017 & 2476,3 & 417,9 & 1486,3 & 572,1 \\
\hline \multicolumn{5}{|c|}{ w odsetkach in the per cent } \\
\hline 1995 & 100,0 & 24,8 & 58,8 & 16,4 \\
\hline 2000 & 100,0 & 22,0 & 61,1 & 16,9 \\
\hline 2005 & 100,0 & 18,9 & 63,9 & 17,2 \\
\hline 2010 & 100,0 & 17,5 & 63,7 & 18,8 \\
\hline 2015 & 100,0 & 16,8 & 61,4 & 21,8 \\
\hline 2016 & 100,0 & 16,8 & 60,7 & 22,5 \\
\hline 2017 & 100,0 & 16,9 & 60,0 & 23,1 \\
\hline
\end{tabular}

Tabela 10

Ludność województwa łódzkiego w wieku 13 lat i więcej według poziomu wykształcenia w latach 2002 i 2011 (za: Narodowy Spis Powszechny 2002, 2011)

Population of the Łódź Voivodeship aged 13 and above by educational level, 2002 and 2011 (after: Narodowy Spis Powszechny 2002, 2011)

\begin{tabular}{|l|c|c|c|c|}
\hline \multirow{2}{*}{$\begin{array}{c}\text { Poziom wykształcenia } \\
\text { Education level }\end{array}$} & \multicolumn{2}{|c|}{2002} & \multicolumn{2}{c|}{2011} \\
\cline { 2 - 5 } & $\begin{array}{c}\text { w tys. } \\
\text { in thousands }\end{array}$ & $\begin{array}{c}\text { w \% } \\
\text { in } \%\end{array}$ & $\begin{array}{c}\text { w tys. } \\
\text { in thousands }\end{array}$ & $\begin{array}{c}\text { w } \% \\
\text { in \% }\end{array}$ \\
\hline $\begin{array}{l}\text { Razem } \\
\text { Total }\end{array}$ & $\mathbf{2 2 5 3 , 4}$ & $\mathbf{1 0 0 , 0}$ & $\mathbf{2 2 3 4 , 1}$ & $\mathbf{1 0 0 , 0}$ \\
\hline $\begin{array}{l}\text { Wyższe } \\
\text { University }\end{array}$ & 208,1 & 9,2 & 360,8 & 16,2 \\
\hline $\begin{array}{l}\text { Srednie i policealne } \\
\text { Secondary and post-secondary }\end{array}$ & 713,6 & 31,7 & 740,0 & 33,1 \\
\hline $\begin{array}{l}\text { Zasadnicze zawodowe } \\
\text { Basic vocational }\end{array}$ & 473,4 & 21,0 & 450,5 & 20,2 \\
\hline $\begin{array}{l}\text { Podstawowe i gimnazjalne } \\
\text { Elementary and secondary school }\end{array}$ & 726,9 & 32,3 & 582,2 & 26,1 \\
\hline $\begin{array}{l}\text { Bez wykształcenia } \\
\text { Lack of the education }\end{array}$ & 100,0 & 4,4 & 34,4 & 1,5 \\
\hline
\end{tabular}

Kobiety w województwie łódzkim (analogicznie jak w całym kraju) były lepiej wykształcone od mężczyzn. W 2011 r. wykształceniem wyższym i średnim legitymowało się bowiem $53,5 \%$ kobiet, podczas gdy w przypadku mężczyzn $44,5 \%$. Warto również odnotować, iż mieszkańcy miast byli lepiej wykształceni od mieszkańców wsi. Na przykład, udział osób z wyższym wykształceniem w miastach wynosił $19,8 \%$, a na wsi $9,5 \%$.

W podziale ludności województwa łódzkiego (w wieku 15 lat i więcej) według deklarowanych w spisie z 2011 r. głównych źródeł utrzymania dominującą kategorię stanowili posiadający własne dochody. Ich udział w ogólnej liczbie ludności wynosił 69,5\% (tab. 11). Własne źródło utrzymania 
najczęściej stanowiły dochody z pracy $(39,1 \%)$, w tym głównie najemnej $(31,2 \%)$. Praca na rachunek własny (łącznie z dochodami z wynajmu), odgrywająca obecnie szczególnie ważną rolę w gospodarce, była głównym źródłem dla utrzymania dla 7,8\% ludności. Udział pozostających na utrzymaniu dochodził do $27,9 \%$. W porównaniu $\mathrm{z}$ wy- nikami spisu z 2002 r. należy zwrócić uwagę na znaczny wzrost udziału deklarujących dochody z pracy najemnej (o 22,1\%) i jednocześnie na obniżenie liczby utrzymujących się z pracy na rachunek własny (o 12,8\%), a także pozostających na utrzymaniu (o 6,3\%).

Tabela 11

Ludność województwa łódzkiego według głównego źródła utrzymania w latach 2002-2011

(za: Narodowy Spis Powszechny 2002, 2011)

Population of the Łódź Voivodeship by main source of income, 2002-2011

(after: Narodowy Spis Powszechny 2002, 2011)

\begin{tabular}{|l|c|c|c|c|}
\hline \multirow{2}{*}{$\begin{array}{c}\text { Wyszczególnienie } \\
\text { Specification }\end{array}$} & $\begin{array}{c}\text { w tys. } \\
\text { in thousands }\end{array}$ & $\begin{array}{c}\text { w \% } \\
\text { in \% }\end{array}$ & $\begin{array}{c}\text { W tys. } \\
\text { in thousands }\end{array}$ & $\begin{array}{c}\text { W \% } \\
\text { in } \%\end{array}$ \\
\cline { 2 - 5 } $\begin{array}{l}\text { Razem } \\
\text { Total }\end{array}$ & $\mathbf{2 6 1 2 , 9}$ & $\mathbf{1 0 0 , 0}$ & $\mathbf{2 5 3 8 , 7}$ & $\mathbf{1 0 0 , 0}$ \\
\hline $\begin{array}{l}\text { Własne źródło utrzymania: } \\
\text { Own source of income: }\end{array}$ & $\mathbf{1 6 9 6 , 6}$ & $\mathbf{6 4 , 9}$ & $\mathbf{1 7 6 4 , 1}$ & $\mathbf{6 9 , 5}$ \\
\hline $\begin{array}{l}\text { dochody z pracy } \\
\text { earned income }\end{array}$ & 877,3 & 33,6 & 991,4 & 39,1 \\
\hline $\begin{array}{l}\text { najemnej } \\
\text { of hired labour }\end{array}$ & 649,5 & 24,8 & 792,9 & 31,2 \\
\hline $\begin{array}{l}\text { na rachunek własny } \\
\text { for the own calculation }\end{array}$ & 227,8 & 8,7 & 198,6 & 7,8 \\
\hline $\begin{array}{l}\text { niezarobkowe źródło } \\
\text { non-profit source }\end{array}$ & 817,9 & 31,3 & 770,0 & 30,3 \\
\hline $\begin{array}{l}\text { Na utrzymaniu } \\
\text { Supported }\end{array}$ & $\mathbf{8 9 3 , 7}$ & $\mathbf{3 4 , 2}$ & $\mathbf{7 0 8 , 8}$ & $\mathbf{2 7 , 9}$ \\
\hline $\begin{array}{l}\text { Nie ustalone źródło } \\
\text { Not established source }\end{array}$ & $\mathbf{2 2 , 6}$ & $\mathbf{0 , 9}$ & $\mathbf{6 5 , 8}$ & $\mathbf{2 , 6}$ \\
\hline
\end{tabular}

Znaczne różnice źródeł dochodów występowały pomiędzy mężczyznami i kobietami. Z pracy utrzymywała się blisko połowa mężczyzn, natomiast jedynie co 3 kobieta, przy czym mężczyźni prawie dwukrotnie częściej $(10,1 \%)$ aniżeli kobiety $(5,7 \%)$ pracowali na rachunek własny. $Z$ uwagi na niższy wiek emerytalny i urlopy macierzyńskie kobiety częściej od mężczyzn korzystały też ze źródeł niezarobkowych. Różnice pomiędzy źródłami utrzymania ludności miast i wsi znajdują odzwierciedlenie przede wszystkim w znacznie niższym w przypadku ośrodków miejskich odsetku osób utrzymujących się z niezarobkowego źródła utrzymania oraz utrzymywanych.

$Z$ punktu widzenia aktywności ekonomicznej ludności istotne znaczenie ma jej podział na trzy kategorie: pracujących, bezrobotnych i biernych zawodowo. Pracujący i bezrobotni (w wieku 15 lat i więcej) są zaliczani do ludności aktywnej zawodowo. W świetle wyników spisu z 2011 r. ludność aktywna zawodowo w województwie łódzkim stanowiła 51,8\% ogółu osób w wieku 15 lat i więcej. Ze względu na uwarunkowania demograficzne i społeczne (wiek emerytalny, przeciętne trwanie życia, funkcje w rodzinie) współczynnik aktywności zawodowej mężczyzn $(59,6 \%)$ był znacznie wyższy niż w przypadku kobiet (44,8\%). W okresie międzyspisowym 2002-2011 dysproporcje w poziomie aktywności zawodowej mężczyzn i kobiet zwiększyły się (z 13,7\% do 14,8\%). Tradycyjnie wyższy współczynnik aktywności zawodowej cechuje ludność miast $(53,1 \%)$ aniżeli wsi (49,5\%), przy czym w porównaniu z 2002 r. na terenach wiejskich wystąpił większy spadek wartości tego współczynnika (o 9,3\%) aniżeli w miastach (o 1,8\%).

W 2011 r. ważnym problemem społecznym w regionie łódzkim było bezrobocie. Liczba bezrobotnych wynosiła tutaj 144,3 tys., a stopa bezrobocia osiągnęła 13,1\% (Polska 13,0\%). Godny uwagi jest duży spadek wartości tego wskaźnika (o 7,1\%) w okresie 2002-2011. Najwięcej bezrobotnych było wśród ludzi młodych, gdyż bez pracy pozostawała ponad $1 / 3$ osób poniżej 30 roku życia. Bezrobocie to cechowało przy tym głównie osoby najsłabiej wykształcone. Po przejściowym niedu- 
żym wzroście stopy bezrobocia w latach 2012 2013 później znacznie się ona obniżyła (do 8,5\% w 2016 r.). W 2011 r. w całym województwie osób biernych zawodowo było 1022,0 tys. W porównaniu z 2002 r. ich liczba wzrosła o 9\%. Wzrost ten obejmował w głównej mierze tereny wiejskie (o 26,6\%), natomiast w miastach liczebność tej grupy wzrosła nieznacznie (o $0,7 \%)$.

Transformacja społeczno-ekonomiczna w Polsce po 1988 roku polegała m.in. na radykalnych przekształceniach struktury działalności gospodarczej. W procesie przekształceń własnościowych zasadniczą rolę odegrały prywatyzacja, reprywatyzacja i komercjalizacja przedsiębiorstw państwowych oraz swoboda w kreowaniu i rozwoju nowych firm prywatnych. Porównywalne dane statystyczne pozwalają na analizę zmian struktury pracujących w województwie łódzkim według sektorów własnościowych i rodzajów działalności w latach 2000-2017 (rys. 14; tab. 12). W podziale pracujących według sektorów własnościowych już na początku tego okresu uwidoczniła się ogromna dominacja pracujących w sektorze prywatnym $(75,5 \%$ ogółu pracujących). Następne lata przyniosły jej umocnienie się; w 2017 r. w sektorze prywatnym pracowało aż $81,6 \%$ wszystkich pracujących. Tym samym zmalał udział pracujących w sektorze publicznym (z 24,5\% do 18,4\%). Dynamicznie zmieniała się również struktura pracujących według rodzajów działalności. W tym przypadku szczególnie charakterystyczny był znaczny spadek udziału pracujących $\mathrm{w}$ rolnictwie (wraz z leśnictwem, łowiectwem i rybołówstwem, z 32,5\% w 2000 r. do $17,8 \%$ w 2017 r.), przy ponad dwukrotnym zwiększeniu udziału pracujących w usługach (z 20,9\% do $54,7 \%$ ). Natomiast odsetek pracujących w przemyśle i budownictwie ulegał niedużym i różnokierunkowym wahaniom.

\section{Struktura społeczno-kulturowa}

Strukturę społeczno-kulturową ludności województwa łódzkiego w wąskim zakresie obrazują dane spisów powszechnych z 2002 i 2011 r. Spis z 2002 r. był pierwszym w latach powojennych, w którym badane były: narodowość, obywatelstwo i język używany w kontaktach domowych. W świetle wyników tego spisu, o znacznej homogeniczności struktury narodowościowej ludności województwa, świadczy fakt, że przynależność do narodowości polskiej zadeklarowało aż 98,1\% stałych mieszkańców województwa.
W przypadku pozostałych najczęściej wymieniana była narodowość romska, rosyjska, niemiecka, ukraińska i czeska. Podczas spisu z 2011 r. zbadano także (po raz pierwszy w powojennej historii polskich spisów powszechnych) tożsamość narodowo-etniczną. Na podstawie wyników tego spisu można stwierdzić, że wśród ludności województwa zdecydowanie dominują $(98,0 \%)$ osoby o jednorodnej, polskiej tożsamości narodowej. W spisie z 2002 r. ustalono, że ludność województwa jest również prawie jednorodna ze względu na obywatelstwo, ponieważ 98,7\% mieszkańców deklarowało obywatelstwo polskie. Tylko 2,5 tys. $(0,07 \%)$ osób podało, że ma jedynie obywatelstwo niepolskie. Zbliżone były wyniki spisu z 2011 r., w którym ustalono, że aż 99,8\% mieszkańców województwa łódzkiego stanowią obywatele polscy. Wśród osób z obywatelstwem niepolskim najwięcej było obywateli: Ukrainy, Niemiec, Indii, Rosji i Armenii. Dane spisu z 2002 r. dowodzą, że językiem polskim w kontaktach domowych posługuje się 97,7\% mieszkańców województwa. Natomiast bardzo niewielu ( $0,06 \%$ ogółu ludności) nie używało tego języka w domu. Osoby, które posługują się w kontaktach $\mathrm{z}$ domownikami dodatkowo lub wyłącznie językiem obcym, najczęściej deklarowały języki angielski lub niemiecki. Również w przypadku spisu z 2011 r. ogromna większość ludności województwa $(97,0 \%)$ podawała używanie języka polskiego w kontaktach domowych.

Dodajmy, że na terenie województwa łódzkiego w 2002 r. przebywało 1,8 tys. imigrantów stale mieszkających za granicą. Z kolei NSP 2011 wykazał, że czasowo w województwie łódzkim zatrzymało się 4,4 tys. imigrantów z zagranicy (w kraju 56,3 tys.). Powyżej 3 miesięcy mieszkało tu 3,2 tys. osób, pochodzących najczęściej z Ukrainy $(12,1 \%)$, Turcji $(6,4 \%)$, Litwy $(6,1 \%)$, Niemiec $(6,0 \%)$ i Rosji $(5,6 \%)$. Były to głównie osoby młode w wieku 20-29 lat, przebywające w miastach badanego regionu. Należy zaznaczyć, iż równocześnie za granicą (powyżej 3 miesięcy) żyło 73,5 tys. mieszkańców województwa łódzkiego (w kraju około 2 milionów), w głównej mierze ludzi młodych. Najczęstszą przyczynę ich emigracji (dla $>73 \%$ ) stanowiła praca. Najwięcej osób wyemigrowało do Wielkiej Brytanii $(30,7 \%)$, Niemiec $(7,5 \%)$, Irlandii $(4,9 \%)$ i Stanów Zjednoczonych (4,1\%). W stosunku do 2002 r. liczba emigrantów $\mathrm{z}$ regionu łódzkiego wzrosła aż 4-krotnie. 


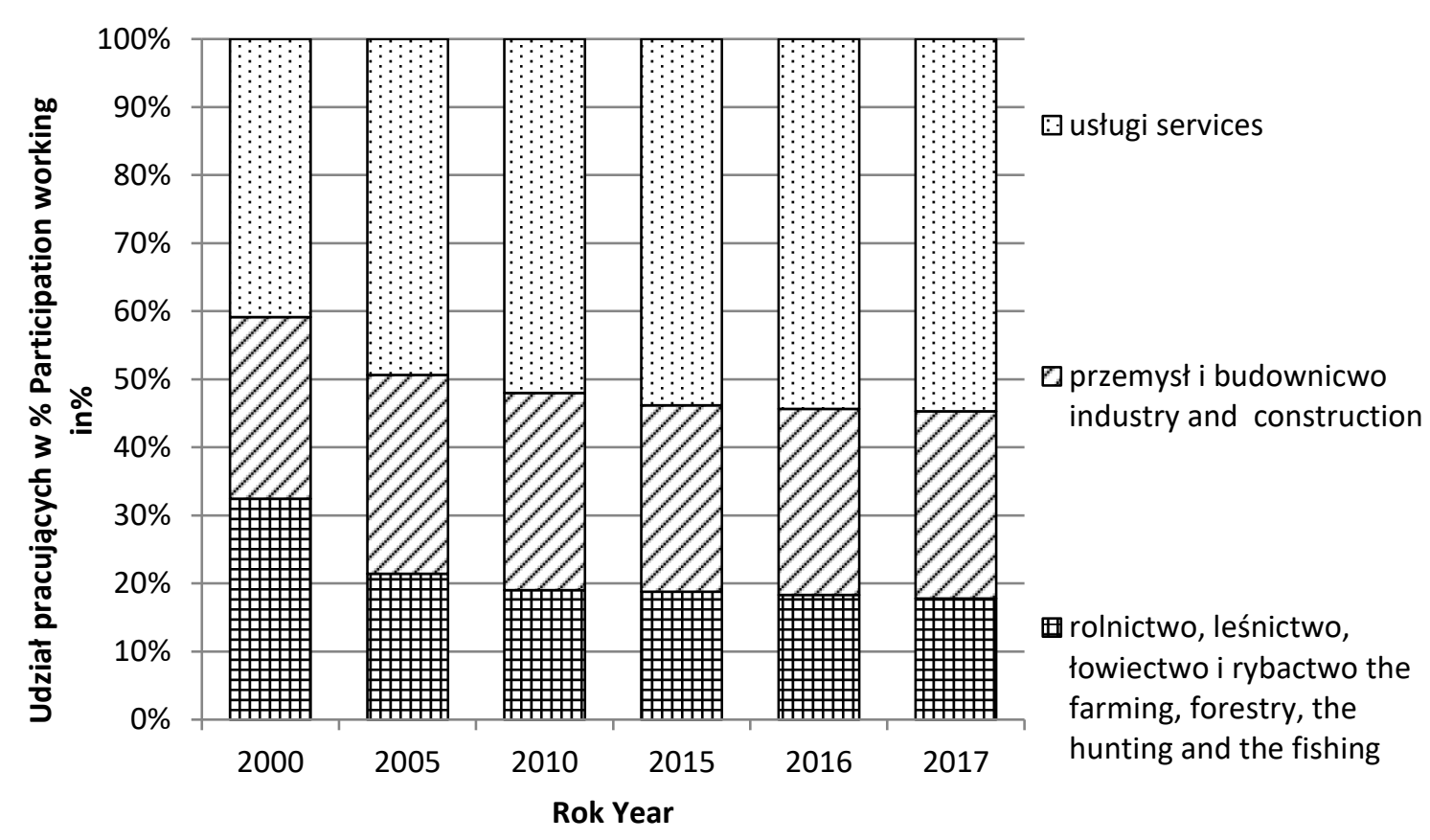

Rys. 14. Pracujący według rodzaju działalności w województwie łódzkim w latach 2000-2016 (za: Roczniki Statystyczne Województwa Łódzkiego 2001-2017)

Working, according to the type of activity, in the Łódź Voivodeship, 2000-2016 (after: Roczniki Statystyczne Województwa Łódzkiego 2001-2017)

Pracujący w województwie łódzkim według sektorów własności i rodzajów działalności w latach 2000-2016 (za: Roczniki Statystyczne Województwa Łódzkiego 2001-2017)

Working in the Łódź Voivodeship by sectors of ownership and activity type, 2000-2016 (after: Roczniki Statystyczne Województwa Łódzkiego 2001-2017)

\begin{tabular}{|c|c|c|c|c|c|c|}
\hline \multirow[b]{2}{*}{$\begin{array}{l}\text { Rok } \\
\text { Year }\end{array}$} & \multirow[b]{2}{*}{$\begin{array}{c}\text { Pracujący } \\
\text { ogółem } \\
\text { w tys. } \\
\text { Working } \\
\text { total }\end{array}$} & \multicolumn{2}{|c|}{$\begin{array}{c}\text { Pracujący wg sektorów } \\
\text { własności w } \% \\
\text { Working according } \\
\text { to sectors of the property }\end{array}$} & \multicolumn{3}{|c|}{$\begin{array}{c}\text { Pracujący wg rodzajów działalności w \% } \\
\text { Working according type of activity }\end{array}$} \\
\hline & & $\begin{array}{c}\text { Sektor } \\
\text { publiczny } \\
\text { Public sector }\end{array}$ & $\begin{array}{c}\text { Sektor } \\
\text { prywatny } \\
\text { Private sector }\end{array}$ & $\begin{array}{l}\text { Rolnictwo, } \\
\text { leśnictwo, } \\
\text { łowiectwo i } \\
\text { rybactwo } \\
\text { The farming, } \\
\text { forestry, the } \\
\text { hunting and } \\
\text { the fishing }\end{array}$ & $\begin{array}{l}\text { Przemysł } \\
\text { i budownictwo } \\
\text { Industry and } \\
\text { conctruction }\end{array}$ & $\begin{array}{l}\text { Usługi } \\
\text { Services }\end{array}$ \\
\hline 2000 & 1066,0 & 24,5 & 75,5 & 32,5 & 26,7 & 40,9 \\
\hline 2005 & 898,6 & 24,1 & 75,9 & 21,4 & 29,2 & 49,3 \\
\hline 2010 & 943,2 & 21,9 & 78,1 & 19,0 & 29,0 & 52,0 \\
\hline 2015 & 956,9 & 19,2 & 80,8 & 18,8 & 27,4 & 53,8 \\
\hline 2016 & 980,4 & 18,8 & 81,2 & 18,3 & 27,3 & 54,3 \\
\hline 2017 & 1005,0 & 18,4 & 81,6 & 17,8 & 27,5 & 54,7 \\
\hline
\end{tabular}




\section{Struktura i typologia przestrzenna ludności}

Struktura i typologia przestrzenna ludności województwa łódzkiego ${ }^{8}$ zostały tutaj przedstawione na przykładzie wyników szczegółowych badań tej problematyki przeprowadzonych na podstawie danych z końca 1999 r. (Dzieciuchowicz 2002), ze względu na trwałość dystrybucji przestrzennej ludności. Wśród ogólnych właściwości rozkładu przestrzennego ludności analizowanego regionu zwraca uwage spadek liczby gmin wraz ze wzrostem ich potencjału ludnościowego, znajdujący swoje odbicie w niezwykle silnej zmienności
$(\mathrm{V}=409,4)$ tego rozkładu $(\mathrm{A}=68,3)$, której towarzyszy wyjątkowo silna prawostronna asymetria i leptokurtoza $(\mathrm{K}=445,6)^{9}$. Mamy bowiem tu do czynienia $\mathrm{z}$ przytłaczającą dominacją małych i średnich gmin, których liczba mieszkańców nie przekracza 10 tys. Do tej kategorii należy 76,8\% wszystkich gmin, rozproszonych dość równomiernie na całym obszarze województwa (rys. 15). Jednakże ogromna większość mieszkańców województwa, gdyż prawie $3 / 4$ (72,2\%), żyje w większych - zazwyczaj zurbanizowanych lub urbanizujących się - gminach, skoncentrowanych przede wszystkim w centralnej części regionu.

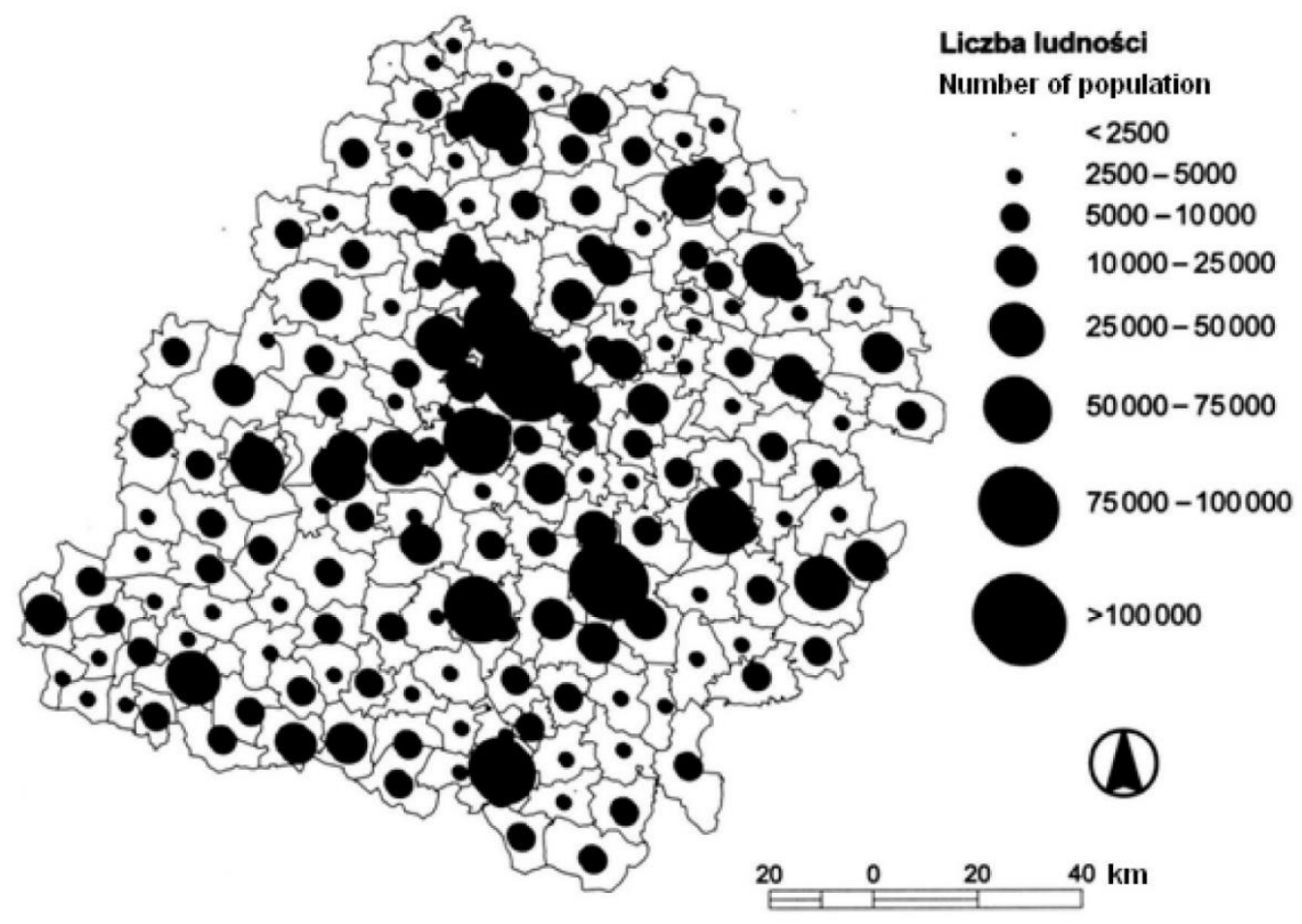

Rys. 15. Rozmieszczenie ludności województwa łódzkiego w 1999 r. (za: Dzieciuchowicz 2002)

Spatial structure of population in the Łódź Voivodeship, 1999 (after: Dzieciuchowicz 2002)

W 1999 r. gęstość ludności na obszarze województwa wynosząca przeciętnie 145,6 osób/ $\mathrm{km}^{2}$, przewyższała poziom ogólnopolski (o 22 osoby $/ \mathrm{km}^{2}$ ), co dowodzi większego tu zaawansowania urbanizacji i uprzemysłowienia. Zmienność gęstości zaludnienia gmin - uzależnioną istotnie od ich stanu ludności $(r=0,58)-$ najkorzystniej będzie przeanalizować w powiązaniu z koncentracją przestrzenną ich zasobów ludnościowych. Stopień tej koncentracji, osiągnięty w skali całego województwa w 1999 r., należy ocenić jako wysoki. Świadczy o tym stosunek koncentracji ludności, którego wartość dochodzi do 0,634. Prawie identyczny wynik uzyskano dla 1995 r. $(0,632)$. Pozwala to wnioskować, iż układ osadniczy rozpatrywanego regionu łódzkiego w latach 1995-1999 wyróżniał się dużą stabilnością, co kontrastuje z równoczesną wyso-

\footnotetext{
8 Indywidualne właściwości układu przestrzennego zaludnienia Polski Środkowej, wynikające $\mathrm{z}$ analizy entropii i zgodności rozkładu empirycznego punktów osadniczych o różnym potencjale ludnościowym z rozkładem Poissona, a także analizy wielkości i kolejności (rank-size) jednostek osadniczych, zostały szeroko omówione w pracy Dzieciuchowicza (1998a).

${ }^{9}$ Symbolami V, A i K są oznaczone odpowiednio współczynniki zmienności, asymetrii (standaryzowane) i kurtozy (standaryzowane), a symbolem $\mathrm{r}$ współczynniki korelacji prostej. Te miary statystyczne, podobnie jak i inne zastosowane w tym opracowaniu, zostały w większości obliczone przy użyciu profesjonalnego programu statystycznego STATGRAPHICS Plus for Windows firmy Manugistics Inc.
} 
ką dynamiką procesów transformacji gospodarczej. Kształt krzywej koncentracji ludności, wybrzuszonej silnie w górnej części, wskazuje, że na ogólnie wysoki poziom tej koncentracji decydujący wpływ wywierają gminy odznaczające się dużą gęstością zaludnienia (rys. 16).

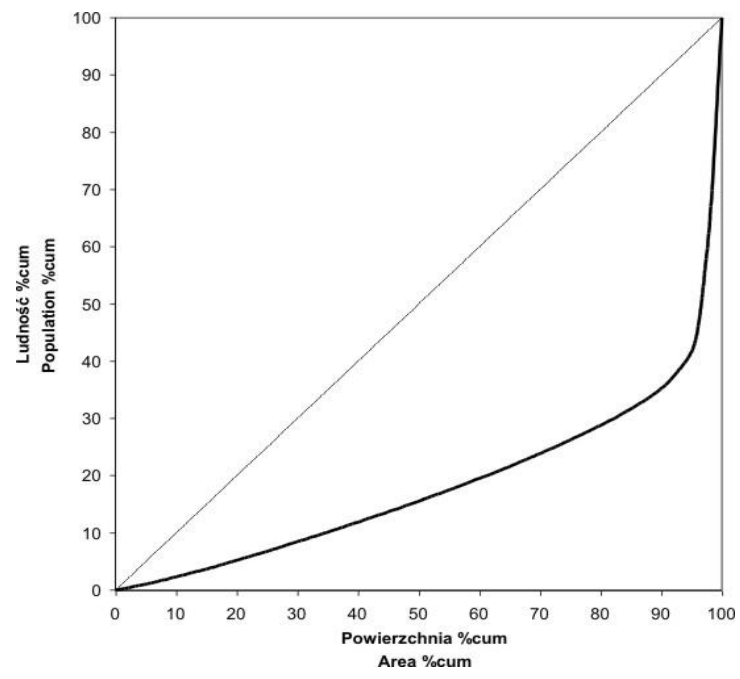

Rys. 16. Stopień koncentracji przestrzennej ludności województwa łódzkiego w 1999 r. (za: Dzieciuchowicz 2002)

Degree of spatial concentration of population in the Łódź Voivodship, 1999 (after: Dzieciuchowicz 2002)

Układ koncentracji przestrzennej ludności województwa łódzkiego można przyrównać do węzłowo-pasmowego (rys. 17). Rolę aktywnych ekonomicznie węzłów, dobrze uprzemysłowionych i wyposażonych $\mathrm{w}$ infrastrukturę techniczną i społeczną, spełniają $\mathrm{w}$ tym układzie większe ośrodki miejskie, zlokalizowane wewnątrz pasm grupujących silniej zurbanizowane lub urbanizujące się gminy wiejskie i mniejsze miasta ${ }^{10}$. Obszary węzłowe, najbardziej podatne na impulsy globalizacyjne i transformacyjne, cechuje wyjątkowo wysoka koncentracja zasobów ludnościowych, gdyż na $60 \%$ ludności województwa przypada tam zaledwie $6 \%$ ogólnej jego powierzchni, a gęstość ludności przekracza 200 osób/ $\mathrm{km}^{2}$. Jądro tego układu tworzy Łódź, w której skupia się $30,2 \%$ wszystkich mieszkańców województwa, przy gęstości zaludnienia dochodzącej aż do 2718 osób $/ \mathrm{km}^{2}$. Od aglomeracji łódzkiej, otaczających to jądro, odchodzi sześć dość silnie zurbanizowanych pasm osadniczych, które mogą odgrywać rolę głównych kanałów przepływu innowacji.
Pasma te biegną - wzdłuż ważnych dróg kołowych i kolejowych oraz komunikacyjnych kanałów drogowo-kolejowych - w kierunku Sieradza-Błaszek, Kutna, Skierniewic-Łowicza, Rawy Mazowieckiej, Tomaszowa MazowieckiegoOpoczna, Piotrkowa Trybunalskiego-Radomska. Oprócz tego zaczynają się formować jeszcze dwa, równoleżnikowe pasma marginalne, rozciągające się wzdłuż osi Kutno-Lowicz oraz RadomskoPajęczno-Wieluń-Wieruszów. Wymienione pasma nie są jednak zupełnie jednolite. Większe ich części, zajmując 39,9\% całkowitej powierzchni województwa, skupiają aż 70\% jego ludności, a gęstość zaludnienia przekracza w nich 60 osób $/ \mathrm{km}^{2}$.

Rolnicze obszary między tymi pasmami odznaczają się silną dekoncentracją przestrzenną ludności, ponieważ $20 \%$ mieszkańców województwa zajmuje tam aż $61,1 \%$ jego całkowitej powierzchni, przy gęstości zaludnienia poniżej $60 \mathrm{osób} / \mathrm{km}^{2}$. Sporadycznie na tych obszarach pojawiają się małe miasta obsługujące swe rolnicze zaplecza. Proces dekoncentracji ludności nasilił się najbardziej w rejonach międzypasmowych, które grupując zaledwie 1/10 zasobów ludnościowych całego województwa, wykorzystują >1/3 $(34,6 \%)$ jego powierzchni. Gęstość ludności nie przekracza tam $50 \mathrm{osób} / \mathrm{km}^{2}$. Największy z takich rejonów, położony między Bełchatowem i Wieruszowem, Rawą Mazowiecką i Drzewicą oraz Opocznem i Przedborzem, należy zarazem do najbardziej zacofanych gospodarczo obszarów omawianego województwa. Rozwój gospodarki rolnej i osadnictwa w tej jego części jest hamowany przez niekorzystne warunki morfologiczne, hydrologiczne i agroekologiczne, niską jakość i przydatność rolniczą gleb (por. Pączka 1993), a także przez niedostateczny rozwój infrastruktury technicznej i społecznej.

Typologię demograficzną gmin badanego województwa oparto na zbiorze 15 cech diagnostycznych (1. Liczba ludności, 2. Liczba osób na $1 \mathrm{~km}^{2}$, 3. Napływ migracyjny na 1000 ludności, 4 . Odpływ migracyjny na 1000 ludności, 5. Przyrost migracyjny na 1000 ludności, 6 . Przyrost rzeczywisty na 1000 ludności, 7. Małżeństwa zawarte na 1000 ludności, 8. Urodzenia żywe na 1000 ludności, 9. Zgony na 1000 ludności, 10. Przyrost naturalny na 1000 ludności, 11. Liczba kobiet na 100 mężczyzn, 12. Udział osób w wieku przedprodukcyjnym w \%, 13. Udział osób w wieku produkcyjnym w \%, 14.

${ }^{10}$ Uwarunkowania demograficzne i społeczno-ekonomiczne redystrybucji przestrzennej ludności aglomeracji łódzkiej zastały szczegółowo przedstawione w pracy Dzieciuchowicza (1995). 

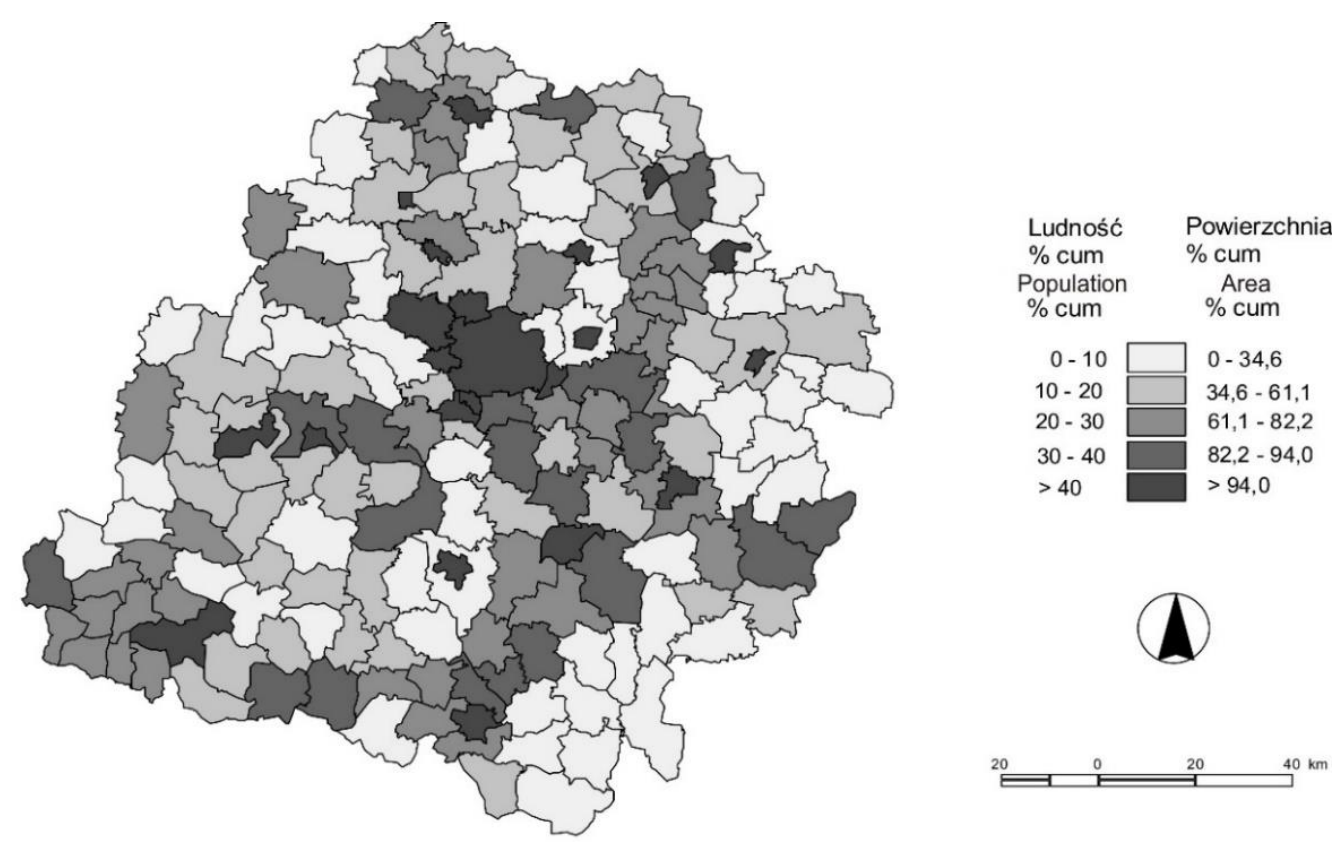

Rys. 17. Koncentracja przestrzenna ludności województwa łódzkiego w 1999 r. (za: Dzieciuchowicz 2002)

Spatial concentration of population in the Łódź Voivodeship, 1999 (after: Dzieciuchowicz 2002)

Udział osób w wieku poprodukcyjnym w \%, 15. Ludność w wieku nieprodukcyjnym na 100 osób w wieku produkcyjnym). Do tego zbioru zostały włączone różnorodne miary opisujące wszechstronnie przestrzenne procesy i struktury ludnościowe, tj. strukturę przestrzenną ludności, ruchy migracyjne, rozwój demograficzny i ruch naturalny oraz strukturę ludności według płci i wieku. Typologii dokonano za pomocą metody K-średnich, opracowanej przez J. MacQueena (Grabiński 1992). Należy ona do kategorii metod iteracyjnooptymalizacyjnych. Pozwala na wydzielenie grup obiektów przy spełnieniu warunku minimalizacji zróżnicowania obiektów w grupie i maksymalizacji tego zróżnicowania między grupami. Grupowanie tego typu odbywa się w trzech etapach, które obejmują: 1 - wyznaczenie losowo (K) obiektów tworzących początkowe skupienia, 2 - przydzielanie kolejnych obiektów do tego skupienia, które leży najbliżej, 3 - przenoszenie obiektów między skupieniami tak, aby uzyskać poprawę jakości podziału.

Zastosowanie metody K-średnich wymagało standaryzacji empirycznych wartości przyjętych cech diagnostycznych ${ }^{11}$ i obliczenia na tej podstawie odległości taksonomicznych między obiektami, reprezentowanymi przez poszczególne gminy (180 jednostek). Za miarę odległości taksonomicznej posłużyła tzw. odległość miejska $(\text { Block })^{12}$. Wykorzystana procedura grupowania umożliwiła wydzielenie w województwie łódzkim 5 typów demograficznych gmin (rys. 18). Każdy z nich reprezentuje specyficzne kombinacje podobnych wariantów wyróżniających cech diagnostycznych.

Typ A: gminy o malym potencjale i silnym regresie demograficznym. Liczne gminy wiejskie tego typu (18,3\%) wyróżnia bardzo mały potencjał ludnościowy (średnio liczą 5,2 tys. mieszkańców) i związana z nim niska gęstość zaludnienia. Ze względu na słabe natężenie napływu migracyjnego i równocześnie wysokie natężenie odpływu, pojawiło się tutaj wysokie ujemne saldo migracyjne. Ponieważ w odpływie ludności $\mathrm{z}$ tych gmin dominują młode kobiety, to feminizacja i udział grupy produkcyjnej reprezentują bardzo niski poziom a jej obciążenie przez pozostałe grupy wiekowe - najwyższy ze wszystkich wydzielonych typów. Jednocześnie dość duże natężenie zgonów jest tu zbieżne $\mathrm{z}$ wysokim udziałem ludności w wieku poprodukcyjnym.

Tradycyjne społeczności wiejskie zamieszkujące tego typu gminy cechuje również dość duże natężenie małżeństw, co pociąga za sobą równie wysoką rodność, a także podwyższony udział grupy

\footnotetext{
${ }^{11}$ Standaryzacji dokonano według formuły: $\mathrm{x}_{\mathrm{ij}} \mathrm{t}=\left(\mathrm{x}_{\mathrm{ij}}-\mathrm{m}_{1 \mathrm{i}}\right) / \mathrm{S}_{\mathrm{xi}}$, gdzie $\mathrm{x}_{\mathrm{ij}}-$ wartość empiryczna cechy $\mathrm{i}$ w jednostce $\mathrm{j}, \mathrm{m}_{1 \mathrm{i}}-$ średnia arytmetyczna cechy $i, S_{x i}-$ odchylenie standardowe cechy $i$.

${ }^{12}$ Odległość miejska jest równa: $\mathrm{d}_{\mathrm{jk}}=\mathrm{d}_{\mathrm{jk}}=\Sigma_{\mathrm{i}}\left|\mathrm{x}_{\mathrm{ij}}{ }^{\mathrm{t}}-\mathrm{x}_{\mathrm{ik}}{ }^{\mathrm{t}}\right|$, gdzie $\mathrm{x}_{\mathrm{ij}}{ }^{\mathrm{t}}$-wartość standaryzowana cechy $\mathrm{i} \mathrm{w}$ jednostce $\mathrm{j}$, $\mathrm{x}_{\mathrm{ik}}{ }^{\mathrm{t}}-$ wartość standaryzowana cechy i w jednostce $\mathrm{k}$.
} 


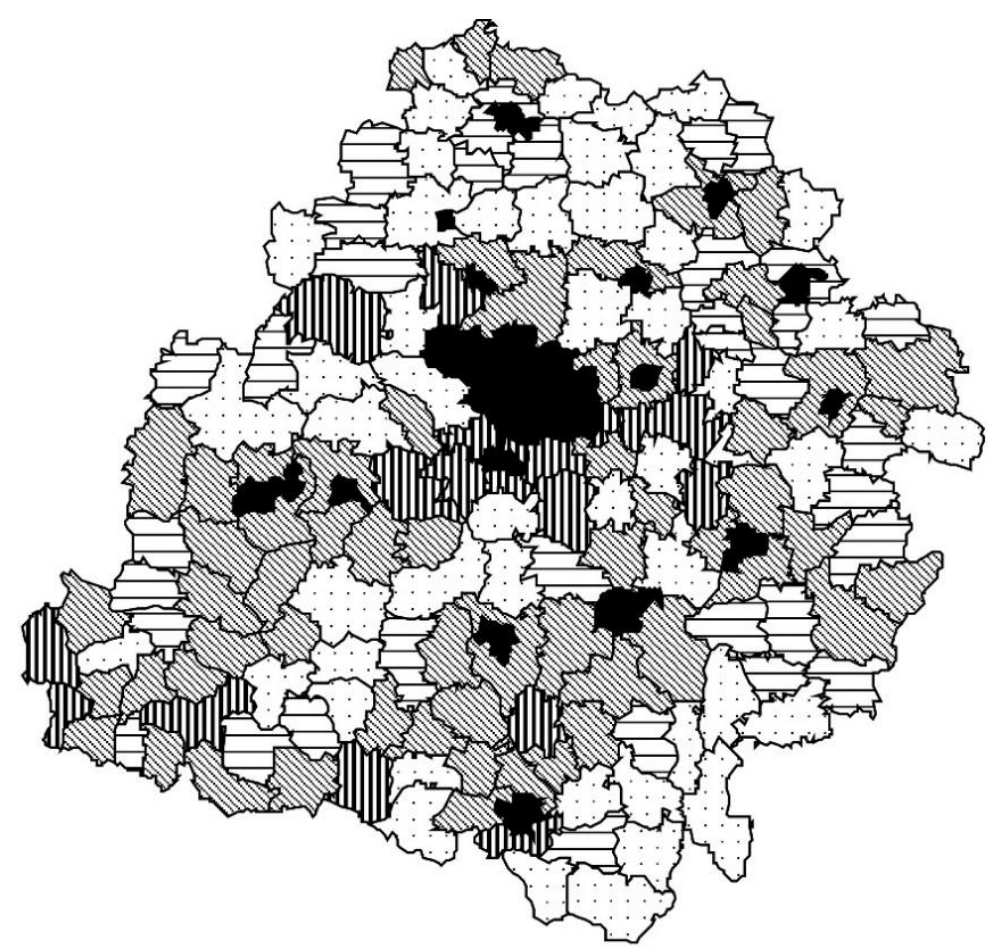

Typy gmin

Types of communities
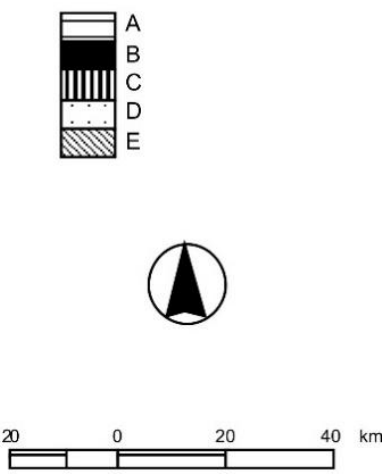

Rys. 18. Przestrzenna typologia demograficzna gmin województwa łódzkiego w 1999 r. (za: Dzieciuchowicz 2002)

Spatial demographic typology of communes of the Łódź Voivodeship, 1999 (after: Dzieciuchowicz 2002)

przedprodukcyjnej i niewielki ujemny przyrost naturalny. Gminy typu A są rozproszone głównie w strefie peryferyjnej regionu łódzkiego. Nierzadko tworzą fragmenty stref wpływów peryferyjnych ośrodków miejskich (Kutno, Łowicz, Skierniewice, Tomaszów Mazowiecki, Piotrków Trybunalski) lub obejmują gminy miejsko-wiejskie (Poddębice, Pajęczno, Wieluń).

Typ B: gminy o bardzo wysokiej koncentracji przestrzennej ludności. Ten typ grupuje około 1/10 wszystkich gmin. Sa to niemal wyłącznie gminy miejskie o bardzo dużych zasobach ludnościowych (przeciętnie 81,4 tys. osób). Napływ migracyjny nieznacznie przewyższa tam odpływ, co zapewnia niewielkie, lecz dodatnie saldo migracji. Słabo zaawansowana depopulacja w tym typie gmin wynika $\mathrm{z}$ ujemnego przyrostu naturalnego, o którym decyduje bardzo niska rodność. Typ B wykazuje bardzo mocno zwichniętą równowagę płci, znajdującą wyraz w ogromnej nadwyżce liczebnej kobiet (110 kobiet/100 mężczyzn), uwarunkowanej długotrwałym ich napływem ze wsi. Łączy się to z wyjątkowo wysokim udziałem produkcyjnej grupy wieku $(63,2 \%)$ oraz z niskim jej obciążeniem pozostałymi grupami wiekowymi. W ten sposób ukształtowana struktura demograficzna sprzyja dużej aktywności ekonomicznej ludności, ale może również rodzić napięcia na rynku pracy. W tym typie gmin bar- dzo niski poziom umieralności jest zbieżny z przeciętnie niewielkim udziałem osób w wieku poprodukcyjnym. Należy jednak zwrócić uwage na zagrożenie dla rozwoju demograficznego tych gmin, wynikające $\mathrm{z}$ niewielkiego natężenia małżeństw, powiązanego $\mathrm{z}$ bardzo niską rodnością $(8,6 \%$ o), która tłumaczy nieduży tam udział dzieci i młodzieży. Do typu B należą wszystkie gminy miejskie oraz jedna gmina miejsko-wiejska Aleksandrów Łódzki.

W tym typie gmin wyraźną indywidualność demograficzną wykazuje Łódź, przede wszystkim ze względu na swój wielkomiejski potencjał demograficzny (800,1 tys. osób) i związaną z nim wyjątkowo wysoką gęstość zaludnienia (2718 osób/ $\mathrm{km}^{2}$ ), a także poważnie zaawansowany proces starzenia demograficznego, znajdujący swoje odbicie w ponadprzeciętnym udziale grupy poprodukcyjnej $(19,0 \%)$, z czym wiąże się również anormalnie wysoka feminizacja ludności (119 kobiet na 100 mężczyzn) oraz duży ujemny przyrost naturalny $(-7,6 \%)$.

Typ C: gminy o wysokiej mobilności przestrzennej ludności. Są to gminy wiejskie i miejsko-wiejskie (10,6\% gmin) o dość dużych zasobach ludnościowych i stosunkowo wysokiej gęstości zaludnienia, odznaczające się szczególnie wysoką mobilnością przestrzenną ich mieszkańców, o czym świadczy wyjątkowo duże prze- 
ciętne natężenie napływu $(17,4 \%$ ) i odpływu $(14,7 \%)$. Znaczna nadwyżka napływu nad odpływem ludności powoduje, że jest to jedyny z 5 typów demograficznych gmin regionu lódzkiego o dodatnim (chociaż niewysokim) saldzie migracyjnym $(2,6 \%)$. W obecnych warunkach demograficznych i społeczno-ekonomicznych atrakcyjność osadnicza takich gmin pośrednio może je predysponować do roli głównych wiodących ognisk integracji społecznej i terytorialnej w badanym regionie.

Ponadto ze względu na swój imigracyjny charakter gminy typu C wykazują dość wysoki poziom feminizacji i podwyższony udział osób w wieku produkcyjnym, nieduże natężenie zgonów, powiązane $\mathrm{z}$ umiarkowanym stopniem starzenia demograficznego. Niezbyt wysokie natężenie małżeństw i w związku z tym również urodzeń pociąga za sobą przeciętny udział grupy przedprodukcyjnej. Typ $\mathrm{C}$ reprezentują głównie silnie zurbanizowane gminy wiejskie aglomeracji łódzkiej oraz gminy miejsko-wiejskie (Poddębice, Kamieńsk, Pajęczno, Wieluń, Wieruszów), a także gminy w strefach wpływów niektórych subregionalnych węzłów osadniczych (Tomaszów Mazowiecki, Radomsko).

Typ D: gminy o wyjątkowo silnej depopulacji. Do tego, licznie w województwie łódzkim reprezentowanego typu (27,2\% gmin), zaliczono gminy wiejskie o niezbyt dużym potencjale ludnościowym i niskiej gęstości zaludnienia. Umiarkowane natężenie napływu migracyjnego jest w tym przypadku zbieżne ze zdecydowanie wyższym natężeniem odpływu. W związku z tym współczynnik migracji netto uzyskał tam, co prawda niewysoką, ale ujemną wartość przeciętną. Jednakże zasadniczą cechą tego typu jest najwyższe (ze wszystkich 5 wyróżnionych typów) natężenie ujemnego przyrostu naturalnego $(-5,9 \%$ ), wynikające w głównej mierze z niezwykle wysokiego poziomu umieralności $(15,2 \%)$. $\mathrm{W}$ tej sytuacji mamy do czynienia $\mathrm{z}$ wyjątkowo dynamiczną w skali badanego województwa depopulacją (ujemny przyrost rzeczywisty $-8,5 \%$ ), która z natury rzeczy przeciwdziała integracji wewnątrzregionalnej. Wśród pozostałych, charakterystycznych cech społeczności reprezentujących analizowany typ warto wymienić dość zrównoważoną strukturę płci oraz bardzo zdeformowaną strukturę wieku, w której najwyższy wśród 5 wydzielonych 5 typów przeciętny udział ma grupa poprodukcyjna (aż 19,7\%), co wskazuje na zbieżność silnej depopulacji z bardzo zaawansowanym rozwojem procesu starzenia demograficznego. Towarzyszy temu wysokie obciążenie grupy produkcyjnej przez nieprodukcyjne grupy wieku
(77,5\%). Typ D rozprzestrzenił się na zacofanych gospodarczo terenach wiejskich, położonych pomiędzy głównymi pasmami rozwoju regionalnego systemu osadniczego, a także w niektórych gminach zlokalizowanych w środkowych lub marginalnych odcinkach tych pasm osadniczych.

Typ E: gminy o zrównoważonych procesach i strukturach demograficznych. Typ ten jest najczęściej spotykany w regionie łódzkim, gdyż należy do niego aż $1 / 3$ gmin o przeciętnych zasobach i koncentracji ludności. Wyróżnia go przede wszystkim ponadprzeciętne natężenie małżeństw i urodzeń, co przy niewysokiej umieralności, sprawia, że pod względem natężenia przyrostu naturalnego $(-0,5 \%)$ uplasował się na najwyższej pozycji ze wszystkich typów. Warto również zauważyć, że gminy tego typu mają charakter imigracyjny, mimo że ich dodatnie saldo migracji trudno uznać za imponujące $(1,2 \%)$. W takiej sytuacji ukształtował się niewysoki, aczkolwiek dodatni przyrost rzeczywisty ludności. Dowodzi to pewnego pokrewieństwa tego typu z typem C. Równocześnie społeczności lokalne gmin typu $\mathrm{E}$ cechuje zrównoważona struktura płci i wieku ludności. Typ E rozwinął się głównie na terenach wiejskich podlegających mniej lub bardziej intensywnej urbanizacji. Są one usytuowane wewnątrz rozwojowych pasm osadniczych, zwłaszcza w ich odcinkach środkowych i peryferyjnych, a także w strefach podmiejskich subregionalnych centrów miejskich. Do tego typu należą również niektóre gminy wiejskie Bełchatowskiego Okręgu Przemysłowego.

\section{Prognoza ludności województwa lódzkiego do 2050 roku}

Prognoza ludności województwa łódzkiego do 2050 roku, opracowana przez GUS, jest niekorzystna $\mathrm{z}$ demograficznego i społeczno-ekonomicznego punktu widzenia. Zakłada bowiem ciągły spadek liczby ludności województwa (rys. 19), uwarunkowany m.in. niekorzystną strukturą wieku. W latach 2020-2050 zaludnienie zmniejszy się tu z 2431,1 tys. do 1999, 1 tys., tj. aż o 435 tys. (o 7,95\%), przy czym dynamika tego spadku wzrośnie $\mathrm{w}$ drugiej połowie prognozowanego okresu, a ubytek ludności w ośrodkach miejskich (389 tys.) będzie dużo większy aniżeli na obszarach wiejskich (46 tys.). W efekcie tych zmian wielkość zasobów ludnościowych wsi stopniowo będzie się zbliżać do liczby ludności miast. Oznacza to postępującą równocześnie $\mathrm{z}$ depopulacją dezurbanizację województwa. 


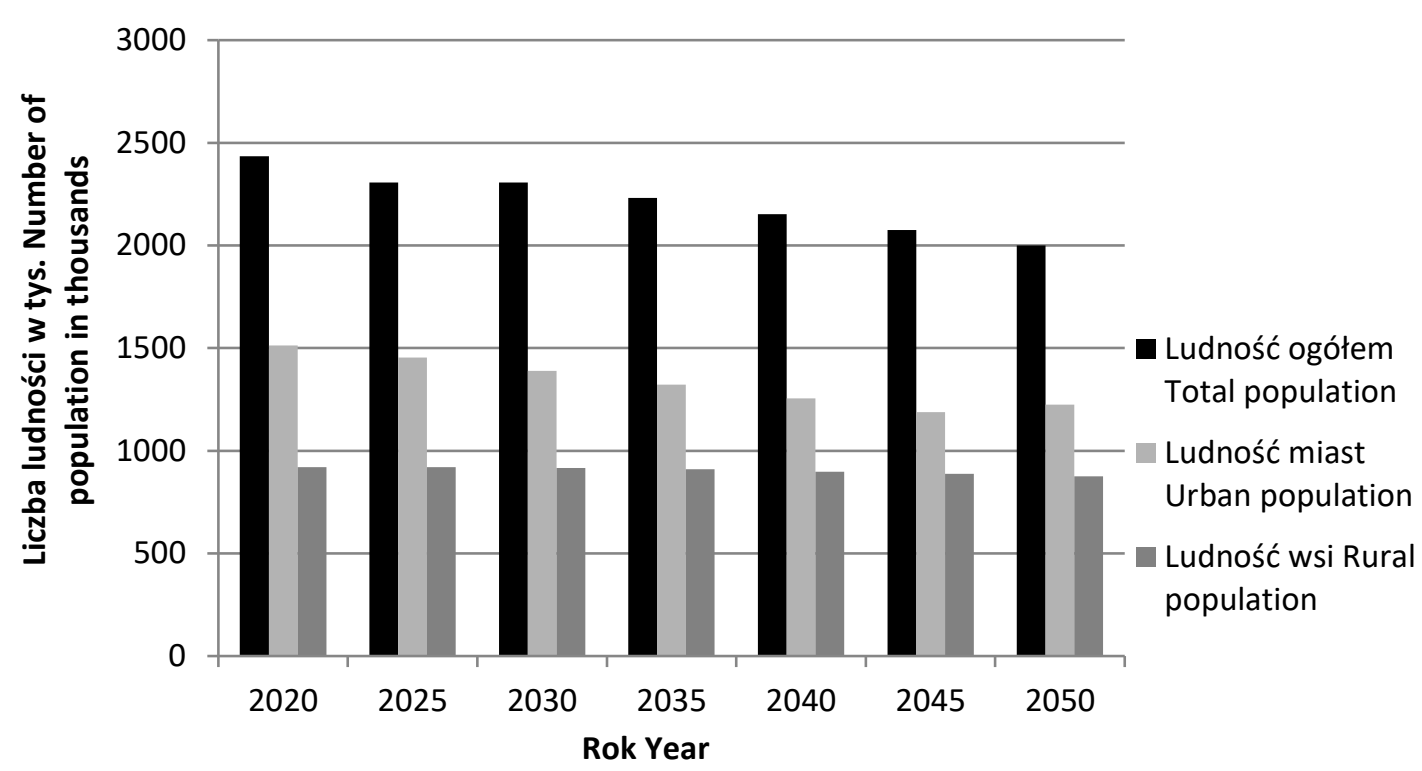

Rys. 19. Prognoza ludności województwa łódzkiego do 2050 roku (za: Rocznik Statystyczny Województwa Łódzkiego 2017)

Population forecast for the Łódź Voivodeship up to 2050 (after: Rocznik Statystyczny Województwa Łódzkiego 2017)

Depopulacji będą towarzyszyć istotne zmiany struktury ludności województwa według płci i wieku. Ponieważ liczba kobiet zmniejszy się bardziej niż mężczyzn, spadnie stopień feminizacji społeczeństwa (ze 109,7 do 106,6 kobiet na 100 mężczyzn). Jednocześnie różnokierunkowym przemianom będzie podlegać struktura wieku ludności. (tab. 13; rys. 20). Nastąpi znaczny spadek liczby osób w wieku przedprodukcyjnym (z 405,2 tys. do 278,9 tys., tj. o 126,3 tys.) i obniży się też udział tych osób w całej strukturze wieku (z 16,6\% do 13,9\%). Będzie to rzutować niekorzystnie na proces reprodukcji demograficznej. Natomiast szczególnie szkodliwy dla rynku pracy będzie bardzo duży spadek liczby osób w wieku produkcyjnym (o 464,3 tys.). Z kolei o dynamicznym rozwoju procesu starzenia demograficznego świadczy wydatny wzrost liczby osób w wieku poprodukcyjnym (z 606,1 tys. do 761,7 tys., tj. o 155,6 tys.) i zwiększenie ich udziału w całej populacji (z 24,9\% aż do $38,1 \%$ ). Skutkiem tych zmian będzie wzrost obciążenia osób w wieku produkcyjnym ludnością w wieku nieprodukcyjnym (z 71 do 109).

\section{Podsumowanie}

Głównym celem autora tej pracy było ustalenie ogólnych tendencji cechujących rozwój i zmiany strukturalne ludności województwa łódzkiego w ciągu ostatnich ponad 100 lat. Szczegó- łowej analizie poddano przemiany ludnościowe w tym regionie w czterech okresach: 1) do 1918 roku, 2) 1918-1945, 3) 1946-1989, 4) 1990-2018. Uwzględniono również prognozę demograficzną województwa do $2050 \mathrm{r}$.

Ustalono, iż początki rozwoju osadnictwa W regionie łódzkim sięgają środkowego paleolitu. W starożytności rozwój ludnościowy regionu związany w głównej mierze z rozprzestrzenianiem się stałego osadnictwa w jego północnej części, na obszarze Pradoliny Warszawsko-Berlińskiej. W średniowieczu rozwój ludnościowy regionu był powolny; Szybszy cechowat jedynie rejony nowo zagospodarowane. Ogromne przyśpieszenie tempa wzrostu demograficznego w regionie zostało zapoczątkowane w XIX w., dzięki rozwojowi przemysłu włókienniczego. Od roku 1819 do 1897 liczba ludności regionu wzrosła ponad 2,5-krotnie: z 636,7 tys. do 1989,2 tys. W XIX w., w wyniku intensywnego napływu Niemców i Żydów oraz migracji rodzimej ludności wiejskiej do rejonów uprzemysławianych ukształtowała się wielonarodowościowa struktura ludności omawianego województwa.

Powstanie województwa łódzkiego w $1919 \mathrm{r}$. (2 VIII) było ważnym impulsem dla jego rozwoju społeczno-ekonomicznego i demograficznego. Województwo to należało wówczas do największych skupisk ludnościowych w kraju. Tempo jego rozwoju demograficznego było jednak wtedy znacznie niższe $\mathrm{w}$ porównaniu z przełomem XIX 
Prognoza ludności województwa łódzkiego według ekonomicznych grup wieku do $2050 \mathrm{r}$. (za: Rocznik Statystyczny Województwa Łódzkiego 2017)

Population forecast for the Łódź Voivodeship by economic age groups up to 2050 (after: Rocznik Statystyczny Województwa Łódzkiego 2017)

\begin{tabular}{|l|c|c|c|c|}
\hline \multirow{2}{*}{$\begin{array}{l}\text { Rok } \\
\text { Year }\end{array}$} & \multirow{2}{*}{$\begin{array}{c}3 \\
\text { Tudność ogółem } \\
\end{array}$} & Total population & \multicolumn{3}{|c|}{\begin{tabular}{c} 
Groups of the age \\
\cline { 3 - 5 }
\end{tabular}} & $\begin{array}{c}\text { przedprodukcyjny } \\
\text { preworking }\end{array}$ & $\begin{array}{c}\text { produkcyjnym } \\
\text { working }\end{array}$ & $\begin{array}{c}\text { poprodukcyjnym } \\
\text { postworking }\end{array}$ \\
\hline \multicolumn{5}{|c|}{ w tysiącach in thousands } \\
\hline 2020 & 2434,1 & 405,2 & 1422,8 & 606,1 \\
\hline 2025 & 2373,7 & 386,7 & 1348,7 & 638,3 \\
\hline 2030 & 2306,4 & 347,9 & 1309,8 & 648,7 \\
\hline 2035 & 2231,6 & 323,1 & 1245,2 & 663,3 \\
\hline 2040 & 2153,0 & 302,3 & 1157,3 & 693,4 \\
\hline 2045 & 2074,9 & 288,7 & 1054,4 & 731,8 \\
\hline 2050 & 1999,1 & 278,9 & 958,5 & 761,7 \\
\hline & & w odsetkach in the per cent & 24,9 \\
\hline 2020 & 100,0 & 16,6 & 58,5 & 26,9 \\
\hline 2025 & 100,0 & 16,3 & 56,8 & 28,1 \\
\hline 2030 & 100,0 & 15,1 & 56,8 & 29,7 \\
\hline 2035 & 100,0 & 14,5 & 55,8 & 32,2 \\
\hline 2040 & 100,0 & 14,0 & 53,8 & 35,3 \\
\hline 2045 & 100,0 & 13,9 & 50,8 & 38,1 \\
\hline 2050 & 100,0 & 13,9 & 48,0 & \\
\hline
\end{tabular}

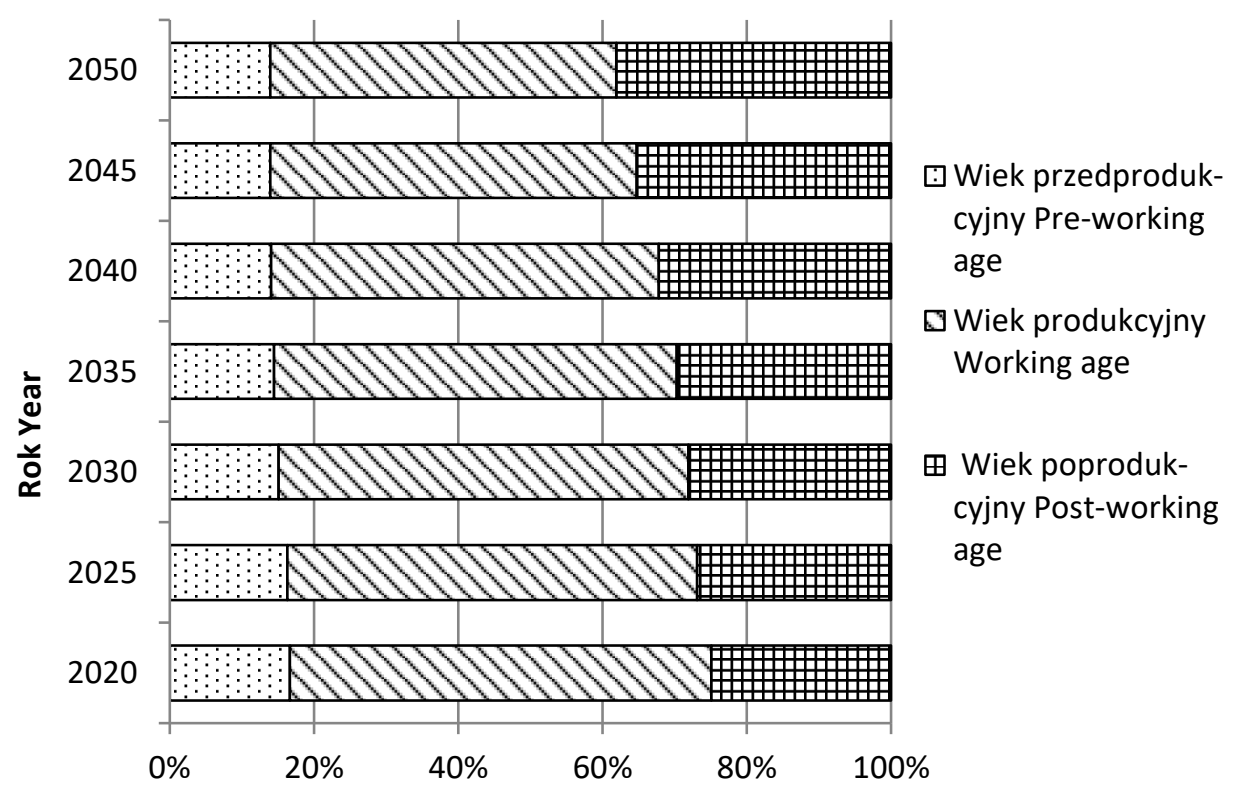

Rys. 20. Prognoza ludności województwa łódzkiego według ekonomicznych grup wieku do 2050 roku (za: Rocznik Statystyczny Województwa Łódzkiego 2017)

Population forecast for the Łódź Voivodeship by economic age groups, up to 2050 (after: Rocznik Statystyczny Województwa Łódzkiego 2017) 
i XX w. Niekorzystnie na dalszy jego rozwój wpłynęło pogorszenie sytuacji gospodarczej regionu w latach 1931-1935. Struktura społeczno-ekonomiczna ludności województwa łódzkiego w okresie międzywojennym była silnie zróżnicowana, przy czym czołową pozycję zajmowali w niej właściciele firm przemysłowych i usługowych oraz gospodarstw rolnych. Nieco mniej liczni byli robotnicy i chałupnicy. Wśród źródeł utrzymania ludności regionu, znacznie zróżnicowanych według wyznań, dominowało rolnictwo, przy dość wysokim i rosnącym udziale przemysłu. Ludność województwa była słabo wykształcona. Na początku lat 20. świadczył o tym m.in. wysoki odsetek analfabetów i osób z wykształceniem tylko początkowym. Później nastąpiła zdecydowana poprawa $\mathrm{w}$ tej dziedzinie. $\mathrm{W}$ okresie międzywojennym społeczeństwo województwa łódzkiego było bardzo zróżnicowane pod względem społecznokulturowym. Dowodzi tego zarówno jego złożona struktura narodowościowa i językowa, jak też wyznaniowa. Zdecydowaną większość w całym województwie stanowily jednak osoby deklarujące narodowość polską, ojczysty język polski i wyznanie katolickie. Spośród mniejszości narodowościowych największe znaczenie mieli Żydzi i Niemcy. Dużo mniej liczne narodowości były reprezentowane w szczególności przez Rosjan, Rusinów (Ukraińców), Białorusinów, Czechów i Litwinów. Zasoby ludnościowe województwa łódzkiego były podzielone nierównomiernie pomiędzy jego poszczególne powiaty. W $1931 \mathrm{r}$. do powiatów o największej liczbie ludności $(38,6 \%)$ należały powiat grodzki łódzki oraz 2 powiaty ziemskie: piotrkowski i wieluński. Wskutek II wojny światowej nastąpił olbrzymi ubytek ludności województwa łódzkiego, sięgający w liczbach bezwzględnych aż do 862 tys. osób. Ubytek ten w równym stopniu dotknął Łódź, jak i pozostałą część województwa. Tylko w samej Łodzi Niemcy wymordowali około 170 tys. Żydów. W wyniku wojny znacznie zdeformowana została struktura ludności, zwłaszcza struktura płci i wieku, a struktury narodowościowa i wyznaniowa stały się prawie jednorodne.

Po zakończeniu wojny następował systematyczny, chociaż stopniowo coraz wolniejszy, wzrost potencjału demograficznego województwa łódzkiego. Ludność województwa (w obecnych granicach) rozwijała się przy tym wolniej, aniżeli ludność całej Polski. Od 1950 do 1988 r. liczba mieszkańców województwa zwiększyła się z 2140,8 tys. do 2703,7 tys., tj. o 562,9 tys. Można przy tym zauważyć, że rozwojowi ludności miejskiej towarzyszyła malejąca liczba ludności wiejskiej. W przypadku samej Łodzi rozwój demograficzny cechował początkowo trend rosnący.
Dopiero w połowie lat 80 . zawężona reprodukcja ludności miasta stała się symptomem drugiego przejścia demograficznego. Przemiany struktury społeczno-zawodowej łodzian znalazły wyraz w dynamicznym wzroście ich poziomu wykształcenia, a także trwałej dominacji osób utrzymujących się z pracy w przemyśle. $Z$ procesem starzenia demograficznego wiąże się wzrost udziału utrzymujących się ze źródeł niezarobkowych, głównie rent i emerytur. Po II wojnie światowej aż do końca lat 80 . następował wzrost homogeniczności struktury wyznaniowej mieszkańców miasta.

Na obszarze województwa łódzkiego (z wyłączeniem samej Łodzi) w okresie 1945-1975 specyficznych właściwości nabierały zarówno rozwój, jak i przemiany strukturalne ludności. $\mathrm{W}$ pierwszych latach powojennych liczba jego mieszkańców zmniejszała się wskutek odpływu migracyjnego. Od 1950 r. zachodził zaś powolny wzrost demograficzny województwa. Jego niewysokie tempo wynikało zarówno z niskiego przyrostu naturalnego, jak i z ujemnego salda migracji.

Jednym $z$ następstw demograficznych II wojny światowej była bardzo silna feminizacja ludności województwa łódzkiego, która w późniejszym czasie, między innymi pod wpływem wysokiego poziomu rodności, stopniowo malała. Wskutek silnego odpływu migracyjnego młodych kobiet z obszarów wiejskich do miast, feminizacja ludności miejskiej była wyższa aniżeli mieszkańców wsi. Istotne przekształcenia struktury wieku ludności województwa były związane w głównej mierze z procesem starzenia demograficznego, zachodzącym przede wszystkim na obszarach wiejskich, z uwagi na nasilony odpływ migracyjny młodzieży do miast. Głębokie przeobrażenia objęły strukturę społeczno-zawodową i społeczno-kulturową ludności rozpatrywanego województwa. Ich wyrazem był szybki ogólny wzrost aktywności zawodowej oraz zatrudnienia $\mathrm{w}$ gospodarce uspołecznionej poza rolnictwem, zwłaszcza w przemyśle. Jednakże nadal najwięcej mieszkańców pracowało w swych gospodarstwach rolnych. Warto również zauważyć, iż po wojnie struktura narodowościowa analizowanego województwa stała się prawie jednorodna. Rozmieszczenie ludności na jego obszarze $-\mathrm{z}$ wyłączeniem Lodzi - w analizowanym okresie było nierównomierne. Na przykład w końcu 1964 r. najwięcej ludności zamieszkiwało w powiatach ziemskich: radomszczańskim, łódzkim i kutnowskim. Na terenie powiatów grodzkich gęstość zaludnienia przekraczała 1000 osób $/ \mathrm{km}^{2}$. W powiatach ziemskich gęstością wyższą od przeciętnej w województwie (97) wyróżniały się powiaty: kutnowski, łęczycki i łódzki. 
W latach 1988-2017 rozwój ludności województwa łódzkiego (w aktualnych granicach) cechowała już ogólna tendencja spadkowa. Liczba mieszkańców zmniejszyła się wówczas aż o 227,4 tys. osób, tj. o 8,4\%. Depopulacja ta stanowi obecnie jeden z najważniejszych problemów demograficznych omawianego regionu. Zarysowaty się przy tym odmienne tendencje w rozwoju demograficznym miast i wsi. Rozwój ludności miejskiej wyróżniał silny trend spadkowy, podczas gdy potencjał ludnościowy wsi podlegał niewielkim, różnokierunkowym zmianom. Rozwój ludnościowy województwa był wolniejszy aniżeli całego kraju. $\mathrm{W}$ analizowanym 30-leciu o wielkości ujemnego przyrostu rzeczywistego ludności decydował bardzo duży ubytek naturalny, ukształtowany w warunkach niewielkiego natężenia zawieranych małżeństw, wysokiej umieralności oraz dość niskiej rodności, płodności i dzietności. Średnie natężenie salda migracyjnego, przy słabo zarysowanej ogólnej tendencji spadkowej i niewielkich oscylacjach, było zaś bardzo niskie.

Wraz z rozwojem ludności województwa łódzkiego w okresie 1989-2017 następowały zmiany jej struktury demograficznej i społecznoekonomicznej. Poziom feminizacji całej populacji wzrósł w niewielkim stopniu, przy czym ujawniły się duże różnice proporcji płci w układzie miastowieś. Zmiany w strukturze ludności województwa w latach 1995-2016, rozpatrywane według ekonomicznych grup wieku, znajdują wyraz głównie w zmniejszeniu udziału osób $\mathrm{w}$ wieku przedprodukcyjnym, przy równoczesnym wzroście tych w wieku poprodukcyjnym. Zmiany te świadczą o dużej dynamice procesu starzenia demograficznego.

Korzystnie o stratyfikacji społecznej w województwie łódzkim świadczy struktura wykształcenia jego mieszkańców. W okresie międzyspisowym 2002-2011 wyraźnie wzrósł odsetek osób z wykształceniem wyższym, przy znacznym spadku odsetka osób z wykształceniem podstawowym i gimnazjalnym, a w mniejszym stopniu także tych bez wykształcenia. Kobiety, podobnie jak w całym kraju, były lepiej wykształcone od mężczyzn. Jednocześnie poziom wykształcenia mieszkańców miast był wyższy niż ludności wsi. W okresie 2002-2011 nastąpił znaczny wzrost liczby osób deklarujących dochody z pracy najemnej i jednoczesny spadek tych utrzymujących się z pracy na rachunek własny, a także pozostających na utrzymaniu (o 6,3\%). Znaczne różnice źródeł dochodów występowały pomiędzy mężczyznami i kobietami, a także w układzie miasto-wieś. Istotny był także duży spadek stopy bezrobocia, zwłaszcza po 2013 r. Zmiany struktury pracujących w woje- wództwie łódzkim według sektorów własnościowych i rodzajów działalności w latach 2000-2016 wyrażały się przede wszystkim we wzroście silnej dominacji pracujących $\mathrm{w}$ sektorze prywatnym i w znacznym spadku udziału pracujących w rolnictwie (wraz z leśnictwem, łowiectwem i rybołówstwem), przy równoczesnym dynamicznym zwiększeniu udziału pracujących w usługach. W świetle wyników spisów z 2002 i 2011 r. ludność województwa łódzkiego cechuje znaczna homogeniczność struktury narodowościowej.

Przeprowadzone badania wykazały również, że w strukturze przestrzennej ludności województwa łódzkiego zaznacza się przytłaczająca dominacja małych i średnich gmin, których liczba mieszkańców nie przekracza 10 tys., a także silna koncentracja przestrzenna ludności, której układ można przyrównać do węzłowo-pasmowego. Typologię demograficzną gmin badanego województwa, oparto na zbiorze 15 cech diagnostycznych, opisujących strukturę przestrzenną ludności, ruchy migracyjne, rozwój demograficzny i ruch naturalny oraz strukturę ludności według płci i wieku. Typologii tej dokonano za pomocą metody K-średnich, opracowanej przez J. MacQueena. Wykorzystana procedura grupowania umożliwiła autorowi wydzielenie 5 typów demograficznych gmin: A gminy o małym potencjale i silnym regresie demograficznym, B - gminy o bardzo wysokiej koncentracji przestrzennej ludności, C - gminy o wysokiej mobilności przestrzennej ludności, D - gminy o wyjątkowo silnej depopulacji oraz E - gminy o zrównoważonych procesach i strukturach demograficznych.

Ogólnie biorąc, przemiany ludnościowe w okresie ponad 100 ostatnich lat przebiegały w województwie łódzkim ze zmienną w czasie dynamiką, zbieżną najpierw z pierwszym, a później drugim przejściem demograficznym. Długotrwały wzrost demograficzny został gwałtownie przerwany wskutek obu wojen światowych, które spowodowały olbrzymi ubytek ludności i radykalne zmiany jej różnorodnych struktur. Regres demograficzny towarzyszył również długotrwałym i głębokim kryzysom ekonomicznym i społecznopolitycznym. Natomiast przyśpieszony wzrost demograficzny, generujący restrukturyzację ludności, cechował pierwsze lata powojenne oraz okresy boomu gospodarczego. Przemiany społeczno-kulturowe zainicjowane w Polsce po 1989 r. oraz przeszłość demograficzna regionu warunkuje nasilający się tu proces depopulacji, który stanowi obecnie dlań jeden z najważniejszych problemów demograficznych. Perspektywy demograficzne regionu do 2050 r. są niekorzystne. 


\section{Literatura}

Badziak K., Baranowski J., Polit K. 2009. Powstanie i główne kierunki aktywności administracji województwa łódzkiego w okresie międzywojennym. W: K. Badziak, M. Łapa (red.) Województwo łódzkie 1919-2009. Studia i materiaty. PTH OŁ, Łódź: 85-102.

Bank Danych Lokalnych, data wejścia 14.02.2019. Warszawa, GUS.

Bauman Z. 2000. Globalizacja, i co z tego dla ludzi wynika. PIW, Warszawa.

Dylik J. 1948. Rozwój osadnictwa w okolicach Łodzi. Acta Universitatis Lodziensis 2: 44-50.

Dzieciuchowicz J. 1989 (1990). Proces redystrybucji przestrzennej ludności aglomeracji wielkomiejskiej (przykład aglomeracji łódzkiej). Przegląd Geograficzny 61(4): 505-522.

Dzieciuchowicz J. 1995. Determinanty demograficzne i społeczno-ekonomiczne redystrybucji przestrzennej ludności aglomeracji miejskich - przykład aglomeracji łódzkiej. Wyd. UŁ, Łódź.

Dzieciuchowicz J. 1998a. Ludność Polski Środkowej: procesy i struktury przestrzenne. W: A. Werwicki (red.) Transformacja społeczno-ekonomiczna Polski Środkowej. Wyd. UŁ, Łódź: 95132.

Dzieciuchowicz J. 1998b. Zmienność przestrzenna zachowań migracyjnych ludności województwa łódzkiego. W: W. Kwiatkowska (red.) Rozwój ekonomiczny. Rynek pracy. Procesy migracyjne $w$ województwie łódzkim. IPiSS, Raport IPiSS 15, Warszawa: 110-137.

Dzieciuchowicz J. 2001. Rozwój, ruch naturalny i migracje ludności. Rozmieszczenie, struktura demograficzna oraz wielkość i struktura zatrudnienia ludności. W: S. Liszewski (red.) Zarys monografii województwa lódzkiego. ŁTN, Łódź: 180-192.

Dzieciuchowicz J. 2002. Zróżnicowanie demograficzne regionu łódzkiego. W: A. Jewtuchowicz, A. Suliborski (red.) Struktury i procesy ksztattujace tódzki region społeczno-gospodarczy. UŁ ZER i OŚ, Łódź: 77-109.

Dzieciuchowicz J. 2014. Ludność Łodzi - rozwój i przemiany strukturalne. Wyd. UŁ, Łódź.

Gawryszewski A. 2005. Ludność Polski w XX wieku. PAN IGiPZK. Monografie 5, Warszawa.

Ginsbert A. 1962. Łódź. Studium monograficzne. Wyd. Łódzkie, Łódź.

Grabiński T. 1992. Metody taksonometrii. Akademia Ekonomiczna w Krakowie, Kraków.

Janczak J. 2001. Przeszłość demograficzna województwa. W: S. Liszewski (red.) Zarys monografii województwa łódzkiego. ŁTN, Łódź: 173-179.

Janiszewska A. 2015. Depopulacja ludności w województwie łódzkim. W: P. Szukalski (red.) Procesy demograficzne $w$ województwie łódzkim w XXI wieku. Wyd. UŁ, Łódź: 11-32.

Klaassen L.H., Paelinck J.H.P., Wagenaar S. 1982. Systemy przestrzenne. PWN, Warszawa.
Koter M., Liszewski S., Suliborski A. 1999. Łódź i region Polski Środkowej. ŁTN, Łódź.

Mały Rocznik Statystyczny 1938, GUS, Warszawa 1938.

Michalski W. (red.) 1995. Region łódzki w dobie transformacji gospodarczej. CUP, BPR w Łodzi, PTG, Łódź.

Narodowy Spis Powszechny. 1921, 1931. Statystyka Polski, GUS.

Narodowy Spis Powszechny. 2002, 2011. Warszawa, GUS.

Olejnik L. 2009. Województwo łódzkie. W: K. Badziak, M. Łapa (red.) Województwo łódzkie 1919-2009. Studia i materiaty. PTH OŁ, Łódź: 221.

Pączka S. (red.) 1993. Środowisko geograficzne Polski Środkowej. Wyd. UŁ, Łódź.

Puś W. 1987. Dzieje Łodzi przemysłowej (zarys historii). Muzeum Historii Miasta Łodzi, CIK. Łódź.

Roczniki Demograficzne. 1996, 1997, 1998, 1999, 2000, 2001, 2002, 2003, 2004, 2005, 2005, 2006, 2007, 2008, 2009, 2010, 2011, 2012, 2013, 2014, 2015, 2016, 2017, 2018. GUS, Warszawa.

Rocznik Statystyczny Województwa Łódzkiego. 1965. WUS, Łódź.

Roczniki Statystyczne Województwa Łódzkiego. 1996, 1997,1998, 1999, 2000, 2001, 2002, 2003, 2004, 2005, 2005, 2006, 2007, 2008, 2009, 2010, 2011, 2012, 2013, 2014, 2015, 2016, 2017, 2018. WUS, Łódź.

Rosin R. (red.). 1970. Rozwój województwa w Polsce Ludowej. PWN, Warszawa.

Rzepkowski A. 2009. Ludność województwa łódzkiego W świetle pierwszego i drugiego spisu ludności II Rzeczypospolitej (30 IX 1921 i 9 XII 1931). W: K. Badziak, M. Łapa (red.) Województwo łódzkie 1919-2009. Studia i materiały. PTH OŁ, Łódź: 199-207.

Straszewicz L. 1967. Województwo łódzkie. Zarys geograficzno-ekonomiczny. PWN, Warszawa.

Szukalski P. (red.) 2015. Procesy demograficzne w województwie łódzkim w XXI wieku. Wyd. UŁ, Łódź.

Werwicki A.L. (red.) 1998. Transformacja społecznoekonomiczna Polski Środkowej. Wyd. UŁ, Łódź.

Województwo łódzkie w XXX-leciu PRL. 1974. WUS, Łódź.

\section{Summary}

The main purpose of this work was to set the general population tendencies characterising the development and structural changes of the Łódź Voivodeship in the period 1919-2018. Population transformations in this region were analysed in detail for four periods: 1) up to 1918; 2) 1918-1945; 3) 1946-1989; and 4) 1990-2018. A demographic forecast of the Łódź Voivodeship was also made for up to 2050. 
It was established that the beginning of the development of settlement in the Łódź region dates back to the mid-Palaeolithic. In antiquity the population growth of the region was connected with the proliferation of the permanent settlement in its northern part in the area of Pradolina Warszawsko-Berlińska. In the Middle Ages the population development of the region was slow. Only areas that developed more recently have experienced faster demographic increase. The pace of demographic growth in the region began greatly to accelerate in the 19th century, thanks to the development of the textile industry. From 1819 to 1897 the region's population rose from 636,700 to $1,989,200$. In the 19 th century, as a result of the intense inflow of Germans and Jews as well as the migration of the native rural population to industrialised areas, the province's population developed a multi-ethnic structure.

The coming into existence of the Łódź Voivodeship in 1919 (2. VIII) gave an important impetus to this socio-economic and demographic development. The province was then among the biggest population centres in the country. The speed of its demographic development was then much lower than at the end of the 19th century and the beginning of the 20th century. The worsening economic situation of the region in 1931-1935 adversely affected this development. The socio-economic structure of the population of the Łódź Voivodeship was greatly diversified in the interwar period. The owners of industrial and service companies and agricultural farms held the leading position. Workers and cottagers were slightly less numerous. Among the sources of income of the region's population, farming dominated (and was highly diverse in terms of religious faith), with quite a high and growing participation of industry. The population of the voivodeship was poorly educated.

In the interwar period the society of the Lódź Voivodeship was clearly socio-culturally divided. This is evidence by its ethnic, linguistic and religious structure. In the province as a whole the population declaring Polish nationality, Polish mother tongue, and Catholic faith constituted an outright majority; however, of the ethnic minorities, Jews and Germany played a significant role. The population in the Łódź province was divided unevenly between individual districts. In 1931 the districts with the largest populations (totalling 38.6\%) were: Łódź city and Piotrków Trybunalski and Wielun.

As a result of World War II there was a huge drop in population in the Lódź province, of as many as 862,000 persons in absolute numbers.
This loss affected the city of Łódź to the same degree as the rest of the province. In Łódź itself, the Germans murdered about 170,000 Jews. The war heavily deformed the structure of the population, especially sex and age structure; meanwhile, ethnic and religious structure became almost homogeneous.

After the war there was a systematic and gradual increase in the demographic potential of the Łódź Voivodeship. The population of the province (within the modern-day borders) also developed more slowly than the population of the entire country. From 1950 to 1988 the number of residents of the province increased from 2,140,800 to $2,703,700$, i.e. by 562,900 . It is also noticeable that a decreasing rural population accompanied a growing trend in the urban population. In the case of Łódź city itself, the population showed an increasing trend. In the middle of the 1980s city's fertility rate fell as a symptom of the second demographic transition. Transformations in the socio-professional structure of inhabitants of Łódź were seen in a dynamic increase in educational level, as well as the long-lasting dominance of people making their living in the industrial sector. Demographic aging is associated with an increased share of persons living from non-profit sources - mainly pensions. From the end of World War II until the end of the 1980s there was an increase in the homogeneity of the religious structure of city dwellers.

In the period 1945-1975 the development and structural transformation of the population of Łódź Voivodship took on unique properties. In the initial years of the post-war period, the number of residents fell as a result of migration outflow. Starting from 1950 we see the slow demographic growth of the province. The low pace of this increase resulted both from the low birth rate, and from the negative balance of migration.

A very strong feminisation of the population of the Łódź Voivodeship was one of the demographic results of World War II, and later, partly under the influence of a high level of child-bearing, this gradually decreased. As a result of the strong migration outflow of young women from rural areas to cities, the feminisation of the urban population was also higher than that of the rural population. Essential transformations in the province population's age structure were connected with the aging demographic process, occurring primarily in rural areas due to the increased migration outflow of young people to cities. Deep transformations spread through the socio-professional and sociocultural population structures of the province. Their examples were a fast general increase in professional activity and in employment in the natio- 
nalised economy, and especially in industry. However, still most residents of the province were employed in individual farms. It is also worth noting that after the war the ethnic structure of the province became almost homogeneous. The population distribution in his area - excluding Łódź city - in the analysed period was uneven. In 1964 most of the population inhabited the districts Radomsko, Łódź and Kutno.

In 1988-2017 population growth in the Łódź Voivodeship (in its modern-day borders) showed a general downward trend. The number of residents in the province then fell by as many as 227,400 persons, i.e. by $8.4 \%$. The large decrease in population currently constitutes one of the most important demographic problems in the region. In addition, there were different tendencies in the demographic development of cities and the countryside. The growth in the urban population showed a strong decreasing trend, while the rural population potential was subject to small, vari-directional changes. The population increase in the voivodeship was slower than the national average. In the entire analysed period a very great natural population decrease, which formed in conditions of low intensity marriage and fertility rates, determined the size of the total increase in the population. The negative migration balance, which demonstrated a poorly outlined general downward trend with small oscillations, was very low.

Alongside population growth in the Łódź Voivodeship in the period 1989-2017, there were also changes in its demographic and socio-economic structure. The level of feminisation of the entire population rose slightly; in addition, big differences in the relative proportions of the sexes became apparent between towns and the countryside. Population shifts in economically active age groups in the province in 1995-2016 are mainly expressed as a drop in the share of the pre-working-age group, alongside a simultaneous increase in the share of persons of a post-working age. These changes attest to great dynamics in the demographic aging process. The structure of educational attainment level illustrates the social stratification of the population of the Lódź province. In the intercensal period 2002-2011 the percentage of persons with a education higher clearly grew, and at the same time the percentage of persons with a primary and secondary education fell sharply, and to a lesser degree also the share of persons without an education. Women, as throughout the country, were better educated than men in the Łódź Voivodeship. Simultaneously, residents' level of education was higher in cities than in the countryside. In the period 2002-2011, there was a significant growth in the number of persons classified as employed workers, while at the same time the number of self-employed persons and those on benefits steadily fell (by 6.3\%). Considerable differences in sources of revenue appear between men and women, as well as between rural and urban populations. Also, a significant fall in unemployment rate was essential, especially after 2013. Changes in the structure of work activities in the Łódź Voivodeship in 2000-2016 is primarily expressed in the growth of a strong dominance of those working in the private sector, in the significant decrease in the share of those working in farming (along with forestry, hunting and fishery), and in the simultaneous dynamic increase in the share of those working in the service sector. In the light of the 2002 and 2011 censuses, the population characteristics of the province can be concluded to have been significantly homogeneous in ethnic structure.

The conducted research also showed that the general properties of the spatial structure of the Łódź Voivodeship population included an overwhelming dominance of small and average-sized communes with resident numbers not exceeding 10,000 , as well as a strong spatial concentration of the population, which resembled a node-beltshaped spatial system. The demographic typology of communes in the explored province was based on a set of 15 diagnostic features describing the spatial structure of the population, migratory movement, demographic development, and the natural movement and structure of populations according to sex and age. This typology was constructed by the K-averages method drawn up by J. MacQueen. The procedure of grouping made it possible to allocate five types of demographic commune: A - communes of low potential and strong demographic decline, $\mathrm{B}$ - communes of very high spatial concentration of population, $\mathrm{C}-$ communes of high spatial mobility of population, D - communes of exceptionally strong depopulation, $\mathrm{E}$ - communes of balanced processes and demographic structures.

Generally, population transformations over the more than 100 last years in the Łódź region proceeded with dynamics that varied with time, coincident from the first demographic transition, and then with the second. The prolonged demographic growth was violently stopped by both the First and Second World Wars. These wars caused a gigantic drop in population and radical changes in diverse population structures. The demographic decline was also accompanied by long-term, deep economic and socio-political crises. Next, there was demographic growth, which restructured the population in the first post-war years, accompanied by 
periods of economic boom. The socio-cultural transformations that followed after 1989, and the previous demographic condition, intensified the depopulation process that presently constitutes one of the most important demographic problems in the Łódź region. In this region a node-belt-shaped spatial arrangement of population concentrations was created. Also, five types of communes are distinguished, characterised by peculiar combinations of demographic features. The demographic prospects of the region up to 2050 are adverse. 